\title{
Zinc Oxide Nanoparticles (ZnONPs) as Nanofertilizer: Improvement on Seed Yield and Antioxidant Defense System in Soil Grown Soybean (Glycine max cv. Kowsar)
}

${ }^{1}$ Yusefi-Tanha, Elham; ${ }^{*}$ Fallah, Sina; ${ }^{2}$ Rostamnejadi, Ali; ${ }^{*}$ Pokhrel, Lok Raj

${ }^{1}$ Department of Agronomy, Faculty of Agriculture, Shahrekord University, Shahrekord, Iran

${ }^{2}$ Department of Electroceramics and Electrical Engineering, Malek Ashtar University of

Technology, Iran. Email: rostamnejadi@mut-es.ac.ir.

${ }^{3}$ Department of Public Health, The Brody School of Medicine, Department of Health Education and Promotion, College of Health and Human Performance, East Carolina University, Greenville, NC, USA.

*Corresponding authors: LR Pokhrel, Phone: 252-737-5587; Email: pokhrell18@ecu.edu. S Fallah, Phone: +983832324428; Email: falah1357@yahoo.com. 


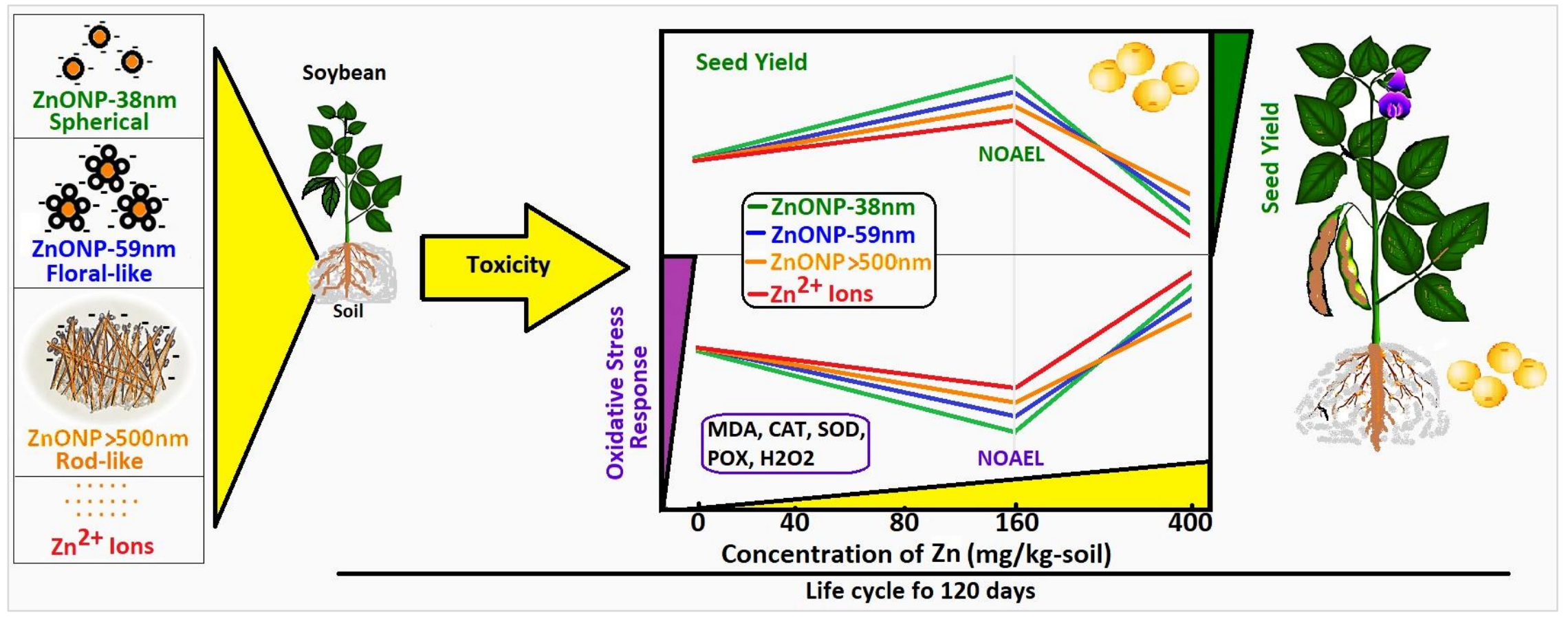

TOC Art 


\section{Highlights}

1. Particle size-, morphology-, and concentration-dependent effects of ZnONPs tested.

2. All $\mathrm{Zn}$ compounds ( $\mathrm{ZnONPs}, \mathrm{Zn}^{2+}$ ) promoted seed yield up to $160 \mathrm{mg} / \mathrm{kg}$.

3. Spherical 38nm ZnONPs elicited the least oxidative stress, except at $400 \mathrm{mg} / \mathrm{kg}$.

4. Concentration-response curves for all $\mathrm{Zn}$ compounds were non-linear.

5. ZnONPs may serve as nanofertilizer for enriching Zn-deficit soil with $\mathrm{Zn}$. 
Abstract: Herein, we investigated potential phytotoxicity of zinc oxide nanoparticles (ZnONPs) on seed yield, focusing on particle size-, morphology-, and concentration-dependent responses of multiple antioxidant defense biomarkers, in soil-grown soybean (Glycine max cv. Kowsar) during its lifecycle. To this end, we synthesized three types of morphologically unique ZnONPs (spherical/ 38nm, floral-like/ $59 \mathrm{~nm}$, and rod-like/ $>500 \mathrm{~nm}$ ); all with high purity, triclinic crystal structure and negative surface charge; and compared the toxicity with $\mathrm{Zn}^{2+}$ ions. Each pot received two seeds, placed in soil inoculated with $\mathrm{N}$-fixing bacteria (Rhizobium japonicum) and grown outdoor for 120 days. Our findings demonstrated a significant particle size-, morphology-, and concentration-dependent influence of ZnONPs on seed yield, lipid peroxidation, and various antioxidant biomarkers in soybean. Our spherical 38nm ZnONPs were the most protective compared to the floral-like 59nm ZnONPs, rod-like $>500 \mathrm{~nm} \mathrm{ZnONPs}$, and $\mathrm{Zn}^{2+}$ ions, particularly up to $160 \mathrm{mg} / \mathrm{kg}$. However, at the highest concentration of $400 \mathrm{mg} / \mathrm{kg}$, spherical 38nm ZnONPs elicited the highest oxidative stress responses $\left(\mathrm{H}_{2} \mathrm{O}_{2}\right.$ synthesis, MDA, SOD, CAT, POX) in soybean compared to the other two morphologically different ZnONPs tested. The concentrationresponse curves for the three types of $\mathrm{ZnONPs}$ and $\mathrm{Zn}^{2+}$ ions were nonlinear (nonmonotonous) for all the endpoints evaluated. The results also suggest differential nano-specific toxicity of ZnONPs compared to ionic $\mathrm{Zn}^{2+}$ toxicity in soybean. Our higher NOAEL value of $160 \mathrm{mg} / \mathrm{kg}$ indicates the potential for ZnONPs to be used as a nanofertilizer for crops grown in Zn-deficient soils to improve crop yield, food quality and address malnutrition, globally.

Key words: Antioxidant enzymes, Zinc oxide nanoparticles, Zinc ions, Reactive oxygen species, Glycine max, Seed yield, Nanofertilizer. 


\section{Introduction}

Nanoscience and nanotechnology imply the study of engineered nanostructures with at least one dimension below $100 \mathrm{~nm}$ with potential for application in a variety of sectors, including in agriculture, therapeutics, diagnostics, engineering, food industry and safety, environmental remediation, and energy infrastructure, among others (National Nanotechnology Initiative, 2005; Du et al., 2019; Malea et al., 2019). Production of engineered nanoparticles (ENPs) for the said applications is exponentially growing primarily due to unique nano-specific physicochemical properties such as high surface area to volume ratio, greater reactivity, high electrical conductivity, high mechanical strength, and antimicrobial properties (Hou et al., 2018; Pokhrel et al., 2012; Rajput et al., 2018).

Growing interests in the use of ENPs in food safety and agriculture can also be attributed to their unique size and surface-related behavior (Nuruzzaman et al., 2016; Dimkpa et al., 2019). ENPs may find use in agriculture in the form of nanofertilizers, growth regulators, or as nanopesticides to address plant and zoonotic diseases. Further, ENPs may serve as sensors in early detection of pathogens and/or degradation of pesticide residue due to higher reactivity (Wang et al., 2016b; Xiong et al., 2017). ZnONPs with unique physiochemical properties may serve as a novel fertilizer for the improvement in crop yield and food quality (Dimkpa and Bindraban, 2018; Hou et al., 2018; White and Gardea-Torresdey, 2018).

Plants are primary producers in virtually every ecosystem, upon which consumers rely (Ma et al., 2010). As such, plants can also uptake and transport various toxicants including ENMs from the biosolid, soil and irrigation water into the edible parts (root, leaf, flower, fruit, seed) (Andreotti et al., 2015; Ogunkunle et al., 2018; Yusefi-Tanha et al., 2020) and serve as a source of exposure to humans and other organisms that feed upon plants. Eventually, toxicants may transport through different trophic levels in the food chain (Zhu et al., 2008; Ghasemi Siani et al., 2017). ENPs may interact with the root surfaces while in the soil or hydroponic media, from where ENPs may traverse through apoplastic and symplastic pathways within the plant cells and thence move up to shoot via the xylem vessel (Deng et al., 2014; Lin and Xing, 2008; Lin et al., 2009; Schwab et al., 2016). It is beginning to be understood that ENPs toxicity on plant growth, metabolism, defense system, and yield may depend on the route of exposure, media composition, dose, particle morphology (size, shape), particle composition, and surface chemistry (Cao et al., 2017; Deng et al., 2017; Pagano et al., 2017; Pokhrel et al., 2012; del Real et al., 2017), including the chemical makeup of the subcellular sites and plant bioassays (Dietz and Herth, 2011; Lin and Xing, 2008; Nuruzzaman et al., 2016; Kranjc et al., 2018; Xiong et al., 2017). Improving knowledge 
on potential factors influencing phytotoxicity, phytotoxicity mechanisms and mitigation measures will support future risk assessment of ENPs.

Several studies have reported positive effects of nanoparticles on plant germination, growth and performance. For example, increased seed germination and growth of seedling, improved photosynthetic efficiency, biomass, and total protein, sugar, nitrogen, and micronutrients were observed in several crop plants; e.g., Vigna radiata and Cicer arietinum (Mahajan et al., 2011), Spinacia oleracea (Srivastava et al., 2014), Cucumis sativus (Moghaddasi et al., 2017), Solanum lycopersicum (Faizan et al., 2018), and Triticum aestivum (Zhang et al., 2018). C. sativus grown in gel chamber showed increased shoot and root biomass with ZnONPs (1 mg/L), and increased shoot length with ZnONPs compared to bulk ZnO (Moghaddasi et al., 2017). When ZnONPs and their derivatives, including $\mathrm{ZnCl}_{2}$, are available in soil in excess, potential toxicity may result in plants (Liu et al., 2015; Mukherjee et al., 2014a; Wang et al., 2016a), including inhibitory effects on seed germination, growth, photosynthesis, physiological and biochemical traits, yield characteristics, and nutritional quality (Du et al., 2017; Zuverza-Mena et al., 2017).

Previous studies have reported potential oxidative stress upon exposure to different ENPs in plants (Mukherjee et al., 2016). Oxidative stress ensues when the equilibrium between reactive oxygen species (ROS) production and defense system in plants is impaired. ROS, which are produced as the by-product of light reaction in chloroplasts during photosynthesis, are implicated in the toxicity elicited by ENPs (Ma et al., 2015) as excess ROS may lead to DNA damage, oxidation of protein, peroxidation of lipid, membrane damage, electrolyte leakage, and eventually, cell death (Demidchik, 2015; Wang et al., 2018). To maintain homeostasis, plants have evolved various strategies that enable protection of cellular and sub-cellular components from potential toxicity of free radicals via deactivating or removing the ROS. These mechanisms consist of both non-enzymatic antioxidants, including the low molecular weight compounds (phenolics, ascorbate, a-tocopherols, glutathione, carotenoids, and proline), and enzymes such as superoxide dismutase (SOD), catalase (CAT), peroxidase (POD), and ascorbate peroxidase (APX), among others (Getnet et al., 2015; Ozyigit et al., 2016). These antioxidants reduce ENP related oxidative injury in plants (Siddiqi and Husen, 2017). MDA is one of the by-products of oxidative stress and ROS that results from the oxidation of unsaturated fatty acids on the cell membrane (Gaschler and Stockwell, 2017).

Recently, we showed particle size (25, 50 and $250 \mathrm{~nm})$ - and concentration-dependent effects of CuONPs on lipid peroxidation, and antioxidant biomarkers including SOD, CAT, POX, and APX, 
in soybean grown in mycorrhiza-enriched soil for a period of 120 days in the outdoor environment (Yusefi-Tanha et al., 2020). Particularly, the effects of 25nm CuONPs were found to be consistently higher for most of the antioxidant biomarkers tested compared to the two larger size CuONPs (CuONPs 50nm, CuONPs 250nm), or $\mathrm{Cu}^{2+}$ ions, treatments. We also showed that the concentration-response curves for $25 \mathrm{~nm}$ CuONPs and $\mathrm{Cu}^{2+}$ ions were linear, unlike for the larger size CuONPs (CuONPs 50nm, CuONPs 250nm) the relationships were nonlinear, for most of the antioxidant biomarkers assessed. The concentration-response curves for seed yield for all types of $\mathrm{Cu}$ compounds were linear $\left(\mathrm{R}^{2}>0.65\right)$. Soybean seed yield also showed particle size- and concentration-dependent inhibition with CuONPs, and inhibition of 25nm CuONPs were significantly higher than the two larger size CuONPs or $\mathrm{Cu}^{2+}$ ions at all concentrations tested. Our results indicated differential nano-specific toxicity compared to ionic $\mathrm{Cu}^{2+}$ toxicity in soybean (Yusefi-Tanha et al., 2020).

Zinc $(\mathrm{Zn})$ is a necessary micronutrient for all plants as it plays a vital role in many physiological activities such as in the biosynthesis of chlorophyll, proteins and enzymes, including in metabolic processes (Singh et al., 2018). For example, $\mathrm{Zn}$ is present within the cytosolic and chloroplastic copper/zinc-SOD enzymes that play a critical role against oxidative stress (Yruela, 2015). Zn metalloproteins are known to partake in replication and transcription of DNA, thereby regulating gene expression (Barker and Pilbeam, 2015). In addition, $\mathrm{Zn}$ is a structural part of the ribosome and responsible for its structural integrity, and takes part in amino acid synthesis and nitrogen metabolism (Barker and Pilbeam, 2015; Kobraee and Shamsi, 2015). Zn is also found in the structure of $\mathrm{CCCH}$-type $\mathrm{Zn}$ finger proteins, that genes encoding them increase the oil content in soybean seed via activating genes related to lipid biosynthesis (Li et al., 2017). In addition, Zn stimulates $\mathrm{N}_{2}$ fixation in legumes, such as French bean (Phaseolus vulgaris L.), by promoting nodule number in roots (Hemantaranjan and Garg, 2015). Deficiency of $\mathrm{Zn}$ in plants is a matter of global concern (Impa et al. 2013), thereby highlighting the potential of supplementing $\mathrm{Zn}$ in the form of nanoparticles as fertilizer (Dimkpa et al., 2015; Du et al., 2019). However, it is noted that at higher concentrations ZnONPs may also cause toxicity in plants (Dimkpa et al., 2015; Liu et al., 2015, wang et al., 2016a).

Soybean, one of the most cultivated and economically important food crops, is rich in protein and oil content and is consumed globally (FAO, 2019; Kanchana et al., 2016). Soil fertilization can affect the nutritional quality of the crop seed such as soybean (Zulfiqar et al., 2019). In this study, we investigated if zinc oxide nanoparticles (ZnONPs) could serve as a novel nanofertilizer, one that could improve crop health and productivity. We tested particle size-, morphology- and 
concentration-dependent responses on seed yield and antioxidant defense system in soil grown soybean (Glycine max cv. Kowsar) during its lifecycle of 120 days. To achieve this goal, we synthesized three types of morphologically different ZnONPs (spherical/ 38nm, floral-like/ 59nm and rod-like/ >500nm); all with high purity, triclinic crystal structure and negative surface charge.

\section{Material and methods}

\section{Synthesis and characterization of $\mathrm{ZnO}$ nanoparticles}

ZnONPs with three different morphologies (spherical/ $38 \mathrm{~nm}$, floral-like/ $59 \mathrm{~nm}$ and rod-like/ $>500 \mathrm{~nm}$ ) were prepared by ball milling and sol-gel methods. Analytical grade zinc acetate dehydrate $\left(\mathrm{Zn}\left(\mathrm{CH}_{3} \mathrm{COO}\right)_{2} .2 \mathrm{H}_{2} \mathrm{O}\right)$ and citric acid $\left(\mathrm{C}_{6} \mathrm{H}_{8} \mathrm{O}_{7}\right)$ were purchased from Merck and used as received. The details of the synthesis process were previously described by Zandi et al. (2011). Briefly, zinc acetate and citric acid (as powder) were mixed in a molar ratio of $1: 1$ and ground for $1 \mathrm{~h}$ at room temperature. The milled powder was calcinated at $530^{\circ} \mathrm{C}$ for $10 \mathrm{~h}$ to obtain ZnONPs $\left(S_{1}\right)$. Samples of ZnONPs with larger particle sizes were also prepared by sol gel method. For this purpose, stoichiometric amounts of zinc acetate and citric acid in the molar ratio of $1: 1$ were dissolved in distilled water. The solution was stirred using a magnetic stirrer at $80^{\circ} \mathrm{C}$ when a viscous gel was obtained. The gel was dried at $100^{\circ} \mathrm{C}$ to transform into powder, then divided into two batches; each batch was calcinated at $800{ }^{\circ} \mathrm{C}\left(\mathrm{S}_{2}\right)$, or $1000{ }^{\circ} \mathrm{C}\left(\mathrm{S}_{3}\right)$ in the air atmosphere. Phase formation and crystal structure of the samples were characterized using $X$ ray diffraction (XRD) in the scanning angle range of $2 \theta=20^{\circ}-80^{\circ}$ using a Philips X'Pert PRO X-ray diffractometer by $\mathrm{Cu}-\mathrm{K} \alpha \mathrm{X}$-ray source $(\lambda=1.5406 \AA)$. Field emission-scanning electron microscopy (FE-SEM) was used to determine particle morphology and diameter. Dynamic light scattering (DLS) was used to estimate hydrodynamic diameter (HDD) and zeta $\zeta$ ) potential (of the ZnONPs synthesized.

\section{Experimental set up}

Our experiments followed a two-way factorial design, which comprised of: $\mathrm{ZnCl}_{2}\left(\mathrm{Zn}^{2+}\right.$; positive control) and ZnONPs with three different morphologies (ZnONP; spherical/ 38nm, floral-like/ $59 \mathrm{~nm}$, and rod-like/ >500 nm) and five different concentrations (0, 40, 80, 160 and $400 \mathrm{mg} \mathrm{Zn/kg)}$. To avoid any spatial effects, the treatments followed a randomized complete design (RCD) with three replicates per treatment, for a total of 60 experimental units with two plants each $(n=120$ plants). All experiments were carried out at Shahrekord University, Iran.

\section{Soil characterization}


Soil was collected from the surface layer (0-30 cm depth). In order to separate wood chips, large clots and rocks, the soil was air-dried and sieved ( $2 \mathrm{~mm}$ mesh). The concentration of background zinc in soil was $0.892 \mathrm{mg} / \mathrm{kg}$. The main physicochemical characteristics of this soil are as follows: classified as silt loam soil ( $16 \%$ sand, $58 \%$ silt, and $26 \%$ clay), with a pH of 7.44 , EC of $0.47 \mathrm{dS} / \mathrm{m}$, $9.24 \mathrm{~g} / \mathrm{kg}$ of organic carbon, $0.88 \mathrm{~g} / \mathrm{kg}$ of total $\mathrm{N}$, and 11.7 and $405 \mathrm{mg} / \mathrm{kg}$ of available $\mathrm{P}$ and $\mathrm{K}$, respectively.

\section{Soil amendment with zinc compound}

For soil amendment, each zinc compound ( $\mathrm{Zn}^{2+}$ and ZnONP: spherical/ 38nm, floral-like/ 59nm and rod-like/ $>500 \mathrm{~nm}$ ) were weighed and suspended in $100 \mathrm{~mL}$ of distilled water to achieve desired concentrations (0, 40, 80, 160 and $400 \mathrm{mg} \mathrm{Zn/kg}$ soil). ZnONPs and $\mathrm{Zn}^{2+}$ ions suspensions were stirred with a magnetic bar for $30 \mathrm{~min}$ at $25^{\circ} \mathrm{C}$ before being added to the soil. Then, different $\mathrm{Zn}$ treatments ( $\mathrm{ZnONP}$ and $\mathrm{Zn}^{2+}$ ) were added to the soil. $\mathrm{ZnCl}_{2}$ was added to soil as an aqueous solution (positive control) to determine potential effects of $\mathrm{Zn}^{2+}$ to soybean. Untreated soil served as the negative control. Three replicates of each treatment were prepared. $\mathrm{ZnONPs}$ and $\mathrm{Zn}^{2+}$ ions in aqueous suspensions were hand mixed with $1 \mathrm{~kg}$ of soil for 30 mins, repeated mixing thrice with $1 \mathrm{~kg}$ soil each time for a total of $4 \mathrm{~kg}$ of soil per pot (to enable homogeneous mixing), and equilibrated in outdoor environment for $24 \mathrm{~h}$ before planting ensued.

\section{Crop management through maturity and seed production}

Briefly, control and amendment soil samples $(4 \mathrm{~kg})$ were placed in PE (polyethylene) bags and put in (20 cm diameter $\times 20 \mathrm{~cm}$ height) PE pots. Each pot had an inner liner of PE mesh (all bags had 50 holes of $5 \mathrm{~mm}$ for drainage), and bottom-filled with a layer of washed gravel (500 g), facilitating aeration and drainage. This design enabled the root system to remain within the bag/pot and facilitated easier plant removal from pot at harvest. Soybean seeds (Kowsar cultivar) were obtained from the Seed and Plant Improvement Institute, Karaj, Iran. They were hydrated in distilled water for $24 \mathrm{~h}$ to facilitate germination. Two seeds with uniform size were planted after inoculation with soybean symbiotic bacteria (Rhizobium japonicum) at $2.5 \mathrm{~cm}$ soil depth $24 \mathrm{~h}$ after soil amendment. This study was performed in microcosm conditions to better understand the real effects of NPs in the environment. During the full growth period, the pots were irrigated based on field capacity. At each irrigation, a sub-sample of water was measured for Zn concentration by inductively coupled plasma-optical emission spectroscopy (ICP-OES). Upon maturity (120 days post-planting), the plants and seeds were harvested. Seeds were air-dried, and weight recorded.

\section{Determination of biochemical parameters}


Two youngest leaves per pot (one leaf each of two plants per pot) were sampled to determine all biochemical parameters tested (Yusefi-Tanha et al., 2020).

\section{Measurement of malondialdehyde concentration}

The level of lipid peroxidation was determined by measuring the formation of malondialdehyde (MDA) content with thiobarbituric acid (TBA) by using the method of Heath and Packer (1968). Briefly, fresh leaf tissue samples $(0.1 \mathrm{~g})$ was homogenized in $1.5 \mathrm{ml}$ of $0.1 \%$ trichloroacetic acid (TCA). The resultant homogenate was centrifuged at $10,000 \times \mathrm{g}$ for $10 \mathrm{~min}$, and $1 \mathrm{~mL}$ of the supernatant was added to $2 \mathrm{ml}$ of $20 \%$ TCA containing $0.5 \%$ TBA. The extract was heated in a water bath at $95^{\circ} \mathrm{C}$ for $30 \mathrm{~min}$ and then quickly cooled in an ice bath. After that, centrifuged at $10,000 \times \mathrm{g}$ for $10 \mathrm{~min}$. The absorbance of the supernatant was read at 532 and $600 \mathrm{~nm}$ against a blank. MDA concentration was expressed in terms of nmol/g FW (by using extinction coefficient of $155 \mathrm{mM}^{-1} \mathrm{~cm}^{-1}$ ) (Narwal et al., 2009).

\section{Estimation of hydrogen peroxide $\left(\mathrm{H}_{2} \mathrm{O}_{2}\right)$}

The hydrogen peroxide produced in leaf of plants was measured following the method previously described by Nag et al. (2000). Fresh leaf tissue $(1 \mathrm{~g})$ was powdered using liquid nitrogen and was homogenized in $12 \mathrm{~mL}$ cold acetone. Then, homogenate was filtered through Whatman filter paper. The mixture was diluted using $4 \mathrm{~mL}$ reagent of titanium $16 \%$, and $0.2 \mathrm{~mL}$ ammonium hydroxide $28 \%$. The tissue extract was further centrifuged at $8500 \mathrm{rpm}$ for $5 \mathrm{~min}$ at $4^{\circ} \mathrm{C}$. The supernatant is isolated and then the precipitate was washed twice with $5 \mathrm{~mL}$ acetone. Finally, added $2 \mathrm{~mL}$ of sulfuric acid (1M), and absorption was measured at $410 \mathrm{~nm}$. The hydrogen peroxide content was calculated using the standard curve prepared in the similar way and expressed as $\mathrm{nmol} / \mathrm{g} \mathrm{FW}$.

\section{Estimation of superoxide dismutase (SOD)}

The tissue samples ( $1 \mathrm{~g}$ of fresh leaf tissue) were frozen in liquid nitrogen and homogenized in $10 \mathrm{~mL}$ of $0.1 \mathrm{M}$ potassium phosphate buffer $(\mathrm{pH} 7.5)$. The tissue extract was further centrifuged at $20,000 \mathrm{rpm}$ for $30 \mathrm{~min}$ at $4^{\circ} \mathrm{C}$. The supernatant was collected, separated into several aliquots and stored at $-20^{\circ} \mathrm{C}$ for determination of antioxidant enzyme activities. The SOD activity was determined by measuring inhibition of the photochemical reduction of nitroblue tetrazolium (NBT) (Narwal et al., 2009). $1.95 \mathrm{~mL}$ of $0.1 \mathrm{M}$ potassium phosphate buffer (pH 7.5), $250 \mu \mathrm{L}$ of $150 \mathrm{mM}$ methionine, $250 \mu \mathrm{L}$ of $1.2 \mathrm{mM} \mathrm{Na} \mathrm{E}_{2} \mathrm{EDTA}, 250 \mu \mathrm{L}$ of $24 \mu \mathrm{M}$ riboflavin, $250 \mu \mathrm{L}$ of $840 \mu \mathrm{M}$ NBT, and $50 \mu \mathrm{L}$ of plant extract were prepared. The reaction was initiated by light illumination and the 
absorbance was read at $560 \mathrm{~nm}$. One unit of SOD activity is defined as the amount of enzyme which causes $50 \%$ inhibition of oxidation reactions per milligram of protein in extract.

\section{Estimation of catalase (CAT) activity}

The CAT activity was determined according to Narwal et al. (2009) by measuring decrement in absorbance at $240 \mathrm{~nm}$ following the decomposition of hydrogen peroxide $\left(\mathrm{H}_{2} \mathrm{O}_{2}\right)$. The reaction mixture consisted of $50 \mu \mathrm{L}$ of supernatant, $1.95 \mathrm{ml}$ of $0.1 \mathrm{M}$ potassium phosphate buffer $(\mathrm{pH} 7.0)$ and $100 \mu \mathrm{L}$ of $264 \mathrm{mM} \mathrm{H}_{2} \mathrm{O}_{2}$. The decrease in absorption was detected for a period of 100 second at 5 second intervals at room temperature $\left(25^{\circ} \mathrm{C}\right)$. One unit of CAT activity corresponds to $1 \mathrm{mMol}$ of $\mathrm{H}_{2} \mathrm{O}_{2}$ consumed per min per mg of protein using an extinction coefficient of $40 \mathrm{mM}^{-1} \mathrm{~cm}^{-1}$.

\section{Estimation of guaiacol peroxidase (POX) activity}

The guaiacol peroxidase (POX) activity was estimated following the method previously developed by MacAdam et al. (1992). Briefly, $50 \mu \mathrm{L}$ of plant extract was added to $1.35 \mathrm{~mL} 0.1 \mathrm{M}$ potassium phosphate buffer (pH 6.0), $100 \mu \mathrm{L} 45 \mathrm{mM}$ guaiacole, and $500 \mu \mathrm{L} 44 \mathrm{mM}$ hydrogen peroxide. Then, we measured kinetic of changes in absorbance at $470 \mathrm{~nm}$ at 10 second interval for 300 seconds at $25^{\circ} \mathrm{C}$ using UV-Vis spectrophotometer. One unit of POX activity corresponds to $1 \mathrm{mMol}$ tetraguaiacol consumed per min. per mg of protein using an extinction coefficient of $26.6 \mathrm{mM}^{-1}$ $\mathrm{cm}^{-1}$.

\section{Estimation of ascorbate peroxidase (APX) activity}

The APX activity was measured by monitoring the rate of ascorbate oxidation with $\mathrm{H}_{2} \mathrm{O}_{2}$, following the method developed by Narwal et al. (2009). The decrease in ascorbic acid, starting from a mixture of $2.4 \mathrm{~mL}$ of $0.1 \mathrm{M}$ potassium phosphate buffer ( $\mathrm{pH} 7.0$ ), $250 \mu \mathrm{L}$ of $1.2 \mathrm{mM} \mathrm{Na} \mathrm{EDTA}_{2}, 50$ $\mu \mathrm{L}$ of $35 \mathrm{mM} \mathrm{H}_{2} \mathrm{O}_{2}, 100 \mu \mathrm{L}$ of $15 \mathrm{mM}$ ascorbic acid, and $200 \mu \mathrm{L}$ of supernatant was measured at $290 \mathrm{~nm}$ over a period of $500 \mathrm{~s}$ at $10 \mathrm{~s}$ interval at room temperature $\left(25^{\circ} \mathrm{C}\right)$. The activity was calculated using an extinction coefficient of $2.8 \mathrm{mM}^{-1} \mathrm{~cm}^{-1}$. One unit of APX was defined as 1 $\mathrm{mMol}$ of ascorbate oxidized per min. per mg of protein.

\section{Estimation of scavenging of $\mathrm{H}_{2} \mathrm{O}_{2}$}

The scavenging of $\mathrm{H}_{2} \mathrm{O}_{2}$ was measured following the method by Benkebila (2005), which measures decrement in UV light absorbance at $230 \mathrm{~nm}$ due to $\mathrm{H}_{2} \mathrm{O}_{2}$ scavenging activity of tested substances/extracts. Each sample was prepared by adding $1 \mathrm{ml}$ of the plant extract and $600 \mu \mathrm{L}$ of fresh prepared $2 \mathrm{mM} \mathrm{H}_{2} \mathrm{O}_{2}$ in phosphate buffer saline (PBS). In another tube a control sample was prepared by adding $1 \mathrm{~mL}$ of PBS and $600 \mu \mathrm{L}$ of fresh prepared $2 \mathrm{mM} \mathrm{H}_{2} \mathrm{O}_{2}$ in PBS. Then, 
the mixtures were left for 10-15 min. at room temperature. Then absorbance was measured at $230 \mathrm{~nm}$.

\section{Statistical analysis}

Data were analyzed with two-way analysis of variance (ANOVA) to examine the interaction between the factors using the least significant difference test using SAS (SAS Inc., ver. 9.4). The differences were considered significant at $p<0.05$ and the means were separated using a Fisher's protected LSD test. The results are presented as the mean \pm standard deviation (SD). To determine if the concentration-response curves were linear (monotonic) or nonlinear (nonmonotonic), we coupled visual inspection of the curves with a simple decision rule: if the coefficient of determination (R-squared) value for the linear regression line is $65 \%$ or higher the concentration-response curves were deemed linear, suggesting that the plant response changes linearly with the concentration applied following the relationship: $y=a x+b$; where $y$ denotes dependent variable, $x$ denotes independent variable, and $a$ and $b$ are model parameters. The computed R-squared values are presented in Supplemental Information (SI) Table S1.

\section{Results}

\section{Nanoparticle characterization}

The analysis of the XRD patterns show that the samples are in triclinic crystalline form with space group p63mc, without any noticeable trace of impurities. The XRD patterns of the powder samples are shown in Fig. 1. The morphology and average particle diameter of the ZnONPs were measured by field emission scanning electron microscopy (FE-SEM). Representative FE-SEM micrographs of the ZnONPs samples and their particle size distributions (PSD) fitted to a lognormal distribution function (as shown in equation 1 below; Rostamnejadi et al., 2017) are presented in Fig. 1:

$f(d)=\frac{1}{d \sigma \sqrt{2 \pi}} \exp \left[-\frac{(\ln d-\ln <d>)^{2}}{2 \sigma^{2}}\right]$

In this relation $<d>$ is the mean particle size and $\sigma$ is the standard deviation. Our analysis of FESEM micrographs of S1 samples showed particles with nearly spherical shape with an average particle diameter of $38 \mathrm{~nm}$ but with dense packing appeared as potential aggregation might have occurred. S2 samples presented floral-like morphology with particle diameter of $59 \mathrm{~nm}$, on average. S3 samples showed spherical particles with average diameter larger than $500 \mathrm{~nm}$ atop microrods of about $1 \mu \mathrm{m}$ in diameter and 10-50 $\mu \mathrm{m}$ in length. All ZnONPs samples (S1-S3) were 
highly negatively charged with over $44.0 \mathrm{mV}$ zeta potential but had variable hydrodynamic diameters (HDDs) (Table 1), a result consistent with the FE-SEM analyses.

\section{Impacts on seed yield}

Our results show the effects of zinc compound types $\left(Z n_{\text {type }}\right)$, zinc concentration $(C)$, and the interaction of $Z n_{\text {type }} \times C$ were statistically significant on seed yield in soybean $(p<0.0001)$ (Table 2). Generally, there was concentration-dependent increase in seed yield for all Zn compounds up to $160 \mathrm{mg} / \mathrm{kg}$, but at the highest concentration tested $(400 \mathrm{mg} / \mathrm{kg}$ ) seed yield significantly declined for all Zn compounds (Fig. 2). Seed yield was highest for spherical $38 \mathrm{~nm}$ ZnONPs compared to floral-like $59 \mathrm{~nm}$ or rod-like $>500 \mathrm{~nm}$ ZnONPs. Seed yield was typically lowest for $\mathrm{Zn}^{2+}$ ions treatments compared to all three types of ZnONPs treatments (Fig. 2), suggesting inhibitory effects of $\mathrm{Zn}^{2+}$ ions on seed yield compared to ZnONPs tested. Further, highest seed yield occurred at $160 \mathrm{mg} / \mathrm{kg}$ for all Zn compound types. Overall, the concentration response curves for all types of Zn compounds were non-linear (Fig. 2; see SI Table S1 for R-squared values), and that the responses were particle size- and morphology-dependent.

\section{Impacts on hydrogen peroxide $\left(\mathrm{H}_{2} \mathrm{O}_{2}\right)$ production}

Our ANOVA showed the effects of $\mathrm{Zn}_{\text {type }}, \mathrm{C}$, and $\mathrm{Zn}_{\text {type }} \times \mathrm{C}$ on leaf $\mathrm{H}_{2} \mathrm{O}_{2}$ production in soybean were significant $(p<0.0001)$ (Table 2). We observed particle size-, morphology- and concentration-dependent influence of $\mathrm{ZnONPs}$ on $\mathrm{H}_{2} \mathrm{O}_{2}$ production in soybean leaf (Fig. 3). With increasing concentrations, $\mathrm{H}_{2} \mathrm{O}_{2}$ production significantly decreased up to $160 \mathrm{mg} / \mathrm{kg}$ for all $\mathrm{Zn}$ compounds; whereas at $400 \mathrm{mg} / \mathrm{kg}, \mathrm{H}_{2} \mathrm{O}_{2}$ production increased significantly for all $\mathrm{Zn}$ compounds, except for rod-like $>500 \mathrm{~nm}$ ZnONPs treatment that showed no significant change compared to control (Fig. 3). Overall, these results suggest that all Zn compounds were protective to soybean up to $160 \mathrm{mg} / \mathrm{kg}$, and that the responses were non-linear (Fig. 3; see SI Table S1 for R-squared values).

\section{Impacts on malondialdehyde (MDA) accumulation}

An accumulation of the MDA-TBA complex was measured to estimate lipid peroxidation in the leaf tissue. Our results showed that MDA content was affected by $Z \mathrm{n}_{\text {type }}(p<0.0001), C(p<0.0001)$, and their interactions $\left(\mathrm{Zn}_{\text {type }} \times \mathrm{C}\right)(p<0.0001)$ (Table 2). We observed particle size-, morphologyand concentration-dependent influence of ZnONPs on MDA levels in soybean leaf (Fig. 3). With increasing concentrations, MDA content significantly decreased up to $160 \mathrm{mg} / \mathrm{kg}$ for all $\mathrm{Zn}$ compounds; whereas at $400 \mathrm{mg} / \mathrm{kg}$, MDA content increased significantly for all Zn compounds, except for rod-like $>500 \mathrm{~nm}$ ZnONPs treatment that showed no significant change compared to 
control (Fig. 3B). As expected, the MDA results mirrored the results of $\mathrm{H}_{2} \mathrm{O}_{2}$ production in leaf suggesting reciprocal relation between $\mathrm{H}_{2} \mathrm{O}_{2}$ production and MDA-TBA accumulation upon lipid peroxidation. Overall, the lipid peroxidation responses were non-linear (Fig. 3; see SI Table S1 for R-squared values).

Impacts on superoxide dismutase (SOD), catalase (CAT) and guaiacol peroxidase (POX) activities

Activities of multiple antioxidant enzymes (SOD, CAT and POX) in soybean leaf exposed to different $\mathrm{Zn}$ compounds are presented in Fig. 4. The effects of $Z \mathrm{n}_{\text {type }}(p<0.0001), \mathrm{C}(p<0.0001)$ and the interaction term $\left(Z \mathrm{n}_{\text {type }} \times \mathrm{C}\right)(p<0.0001)$ were statistically significant on the antioxidant enzymes (SOD, CAT, and POX) activities in soybean leaves. Similar to the $\mathrm{H}_{2} \mathrm{O}_{2}$ production and subsequent MDA accumulation documented above, we observed particle size-, morphology- and concentration-dependent influence of ZnONPs on SOD, CAT and POX activities in soybean leaf (Fig. 4). With increasing concentrations, these antioxidant enzyme activities were significantly reduced up to $160 \mathrm{mg} / \mathrm{kg}$ for all the $\mathrm{Zn}$ compounds; whereas at $400 \mathrm{mg} / \mathrm{kg}$, these enzyme activities increased significantly for all Zn compounds, except for rod-like $>500 \mathrm{~nm}$ ZnONPs treatment that showed no significant difference in the enzyme activities compared to control (Fig. 4). Overall, these results suggest that all three antioxidant enzymes' activities were consistent with the trend for $\mathrm{H}_{2} \mathrm{O}_{2}$ synthesis and MDA accumulation responses, and that the enzymes' responses were non-linear (Fig. 4; see SI Table S1 for R-squared values).

\section{Impacts on ascorbate peroxidase (APX) and $\mathrm{H}_{2} \mathrm{O}_{2}$ scavenging activities}

The effects on APX and $\mathrm{H}_{2} \mathrm{O}_{2}$ scavenging activities in soybean leaf exposed to different $\mathrm{Zn}$ compounds are depicted in Fig. 5. ANOVA showed the effects of $\mathrm{Zn}$ concentration $(\mathrm{C})$ and the interaction term $\left(Z n_{\text {type }} \times C\right)$ were statistically significant on APX activity $(p<0.0001)$ in soybean leaf. Whereas, the effects of $Z \mathrm{n}_{\text {type }}, \mathrm{C}$ and the interaction term $\left(Z \mathrm{n}_{\text {type }} \times \mathrm{C}\right)$ were all statistically significant on $\mathrm{H}_{2} \mathrm{O}_{2}$ scavenging $(p<0.0001)$ in soybean leaf. Overall, the APX responses of soybean upon exposure to different types of $\mathrm{Zn}$ compounds were opposite to that of $\mathrm{H}_{2} \mathrm{O}_{2}$ scavenging activities observed.

For the APX activity, which measured the ascorbate oxidation rate in the presence of added $\mathrm{H}_{2} \mathrm{O}_{2}$, we observed particle size-, morphology- and concentration-dependent influence of ZnONPs in soybean leaf (Fig. 5A). With increasing concentrations, APX activity was significantly reduced up to $160 \mathrm{mg} / \mathrm{kg}$ for all the $\mathrm{Zn}$ compounds tested; whereas at $400 \mathrm{mg} / \mathrm{kg}$, APX activity increased significantly for all Zn compounds compared to control (Fig. 5A). Further, spherical 38nm ZnONPs 
were the most protective than all other $\mathrm{Zn}$ compounds tested (floral-like 59nm ZnONPs, rod-like $>500 \mathrm{~nm} \mathrm{ZnONPs}$, and $\mathrm{Zn}^{2+}$ ions) up to $160 \mathrm{mg} / \mathrm{kg}$; but at the highest concentration (400 mg/kg) the toxicity trend reversed, i.e., $\mathrm{Zn}^{2+}$ ions were most protective than spherical $38 \mathrm{~nm} \mathrm{ZnONPs}$. Overall, at $400 \mathrm{mg} / \mathrm{kg}$ all $\mathrm{Zn}$ compounds showed significantly higher APX activity (protective response) compared to control (Fig. 5A). Moreover, the APX responses for all Zn compounds were non-linear (Fig. 5A; see SI Table S1 for R-squared values).

Our analysis of $\mathrm{H}_{2} \mathrm{O}_{2}$ scavenging ability of different ZnONPs showed particle size-, morphologyand concentration-dependent influence of ZnONPs in soybean leaf (Fig. 5B). With increasing concentrations, $\mathrm{H}_{2} \mathrm{O}_{2}$ scavenging was significantly reduced up to $160 \mathrm{mg} / \mathrm{kg}$ for all the $\mathrm{Zn}$ compounds tested; whereas at $400 \mathrm{mg} / \mathrm{kg}$, the scavenging activity increased significantly for all Zn compounds compared to control (Fig. 5B). Further, spherical 38nm ZnONPs were least effective in scavenging leaf $\mathrm{H}_{2} \mathrm{O}_{2}$ than all other $\mathrm{Zn}$ compounds tested (floral-like 59nm $\mathrm{ZnONPs}$, rod-like $>500 \mathrm{~nm} Z \mathrm{nONPs}$, and $\mathrm{Zn}^{2+}$ ions) up to $160 \mathrm{mg} / \mathrm{kg}$; but at the highest concentration (400 $\mathrm{mg} / \mathrm{kg}$ ) the scavenging trend reversed for NPs, i.e., spherical 38nm ZnONPs were most effective in scavenging leaf $\mathrm{H}_{2} \mathrm{O}_{2}$ than two other $\mathrm{ZnONPs}$ tested (floral-like 59nm ZnONPs, rod-like >500nm

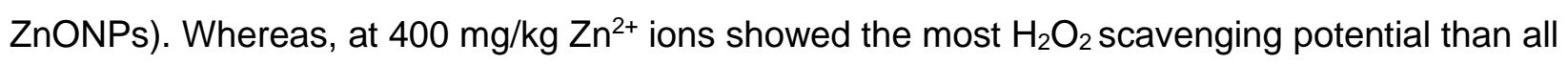
three types of $\mathrm{ZnONPs.} \mathrm{Overall,} \mathrm{leaf} \mathrm{H}_{2} \mathrm{O}_{2}$ scavenging responses for all $\mathrm{Zn}$ compounds were nonlinear (Fig. 5B; see SI Table S1 for R-squared values).

\section{Discussion}

Previous studies have documented variable toxicity of ZnONPs in soybean and other plants. However, most of these studies only focused on one size ZnONPs, thereby limiting our understanding about how some key physicochemical factors such as size, morphology (shape) and surface charge could play a role in nanotoxicity. For example, exposure to $18 \mathrm{~nm}$ ZnONPs led to increased chlorophyll content, shoot height, and grain yield in winter wheat, while plant biomass remained unaffected (Dimkpa et al., 2018). Foliar application of nanocomposites of $\mathrm{ZnO}$, $\mathrm{CuO}$, and $\mathrm{B}_{2} \mathrm{O}_{3}$ showed a significant increase in soybean biomass, grain count, grain biomass, and uptake of micro- and macro nutrients (Dimkpa et al., 2017a). Pod frequency increased in soybean exposed to ZnONPs, whereas the size and mean number of seed per pod did not differ between treatments (Priester et al., 2012). Wheat biomass and grain yield were promoted by $72 \%$ and 55\%, respectively, upon $\mathrm{ZnSO}_{4}$ treatment, while ZnONPs treatment led to $63 \%$ and $56 \%$ increase in biomass and grain yield, respectively, compared to control (Du et al., 2019). However, in Vigna unguiculata grown in soil amended with soluble $\mathrm{Zn}^{2+}$ ions or $\mathrm{ZnONPs}$ showed no 
significant difference in plant growth between the two Zn compounds (Wang et al., 2013). Plant uptake and transport of NPs to aerial plant parts have been previously documented for other types of NPs exposures (Mueller and Nowack, 2008; Shang et al., 2019), leading to decreased plant biomass (Ma et al., 2015a; Shang et al., 2019). As previously discussed, $\mathrm{Zn}$ is required for plants to execute many physiological activities such as the biosynthesis of proteins and enzymes, chlorophyll, and normal functioning of the metabolic processes (Singh et al., 2018). In this study, seed yield was highest for spherical 38nm ZnONPs compared to floral-like 59nm ZnONPs or rodlike $>500 \mathrm{~nm}$ ZnONPs (Fig. 2) up to $160 \mathrm{mg} \mathrm{Zn/kg} \mathrm{treatments.} \mathrm{Seed} \mathrm{yield} \mathrm{was} \mathrm{generally} \mathrm{reduced}$ with $\mathrm{Zn}^{2+}$ ions treatments compared to all three types of ZnONPs treatments (Fig. 2), suggesting an inhibitory effect of $\mathrm{Zn}^{2+}$ ions on soybean seed development compared to $\mathrm{ZnONPs}$ evaluated. While we did not measure potential uptake of ZnONPs in soybean, it is possible that the biochemical processes discussed above (Chandra et al., 2014; Shaw and Hossain, 2013; Da Costa and Sharma, 2016) might have been altered with exposure to soluble $\mathrm{Zn}^{2+}$ ions and ZnONPs, potentially promoting (at $40-160 \mathrm{mg} / \mathrm{kg}$ ) or inhibiting (at $400 \mathrm{mg} / \mathrm{kg}$ ) seed yield. Taken together, our results suggest differential effects of ZnONPs compared to $\mathrm{Zn}^{2+}$ ions treatments (Fig. 2). Further, reduced energy demand due to diminished antioxidative enzymes (SOD, CAT, POX, and APX) (Kurutas, 2016; Yusefi-Tanha et al., 2020) being expressed up to $160 \mathrm{mg} / \mathrm{kg}$ of $\mathrm{ZnONPs}$ or $\mathrm{Zn}^{2+}$ ions treatments might explain increased seed yield, and the inverse response at $400 \mathrm{mg} / \mathrm{kg}$ of $\mathrm{ZnONPs}$ or $\mathrm{Zn}^{2+}$ ions treatment.

Tolerance of plants to metal-based nanoparticles exposure is determined by their ability to protect efficient antioxidant systems meant for scavenging or removal of the excess $\mathrm{ROS}\left(\mathrm{H}_{2} \mathrm{O}_{2}, \mathrm{OH}^{-}\right)$ within the cells and tissues. Previous studies have shown lower toxicity of bulk $\mathrm{ZnO}$ compared to ZnONPs (Amooaghaie et al., 2016; Mukherjee et al., 2014a), and that ZnONPs of small size were transformed into larger sized aggregates within the plant cell, complicating toxicity assessment (Lee et al., 2013). Toxicity induced by the higher concentration of $\mathrm{Zn}$ (400 mg Zn/kg) is manifested as potential interference with key antioxidative enzyme activities as depicted in Figs. 2-5A. $\mathrm{H}_{2} \mathrm{O}_{2}$ is toxic to the cell, particularly, at higher levels, so plants must maintain a balance in the cell to minimize its level to avoid oxidative stress and potential lipid peroxidation (Das and Roychoudhury, 2014). Previous works have shown increased ROS with exposure to higher concentrations of $<100 \mathrm{~nm}$ ZnONPs $(500 \mathrm{mg} \mathrm{Zn/kg}$ ) in wheat (Dimkpa et al., 2012) or 90nm ZnONPs (800 mg/kg soil) in maize (Liu et al., 2015). The hydroxyl $\left(\mathrm{OH}^{-}\right)$radical, the most reactive among all ROS, is produced from $\mathrm{H}_{2} \mathrm{O}_{2}$ as an outcome of dismutation, and is able to separate hydrogen atom from a methylene $\left(\mathrm{CH}_{2}\right)$ group in the lateral chains of polyunsaturated fatty acids 
of membrane lipids thus initiating lipid peroxidation (Shaw et al., 2014). Our observation of particle size-, morphology- and concentration-dependent influence of ZnONPs on MDA accumulation in soybean as a response to $\mathrm{H}_{2} \mathrm{O}_{2}$ synthesis and lipid peroxidation in leaf is unique to nanophytotoxicity study (Fig. 3). Nair and Chung (2014a) observed a significant increase in $\mathrm{H}_{2} \mathrm{O}_{2}$ in soybean seedling roots upon exposure to different CuONP concentrations. Reduced lipid peroxidation (MDA level) observed with exposure to rod-like ZnONPs $>500 \mathrm{~nm}$, especially at the highest concentration $(400 \mathrm{mg} / \mathrm{kg}$ ), may indicate the lack of particle transport in the plant owing to its larger particle size and rod-like morphology, which may have conferred significant protection to cell membrane integrity compared to other two types of ZnONPs and $\mathrm{Zn}^{2+}$ ions. These results are consistent with the previous study that showed a threshold for protective effect beyond which toxicity can manifest for ZnONPs in onion root cells (Kumari et al., 2011).

Hernandez-Viezcas et al. (2011) reported increased CAT activity in root, shoot and leaves at different concentrations (500-4000 mg/L) of $10 \mathrm{~nm}$ ZnONPs treatments, but at concentrations higher than $500 \mathrm{mg} / \mathrm{L}$ APX activity was reduced. Allium cepa exposed to ZnONPs of $\sim 85 \mathrm{~nm}$ (200, 400 , and $800 \mathrm{mg} / \mathrm{L}$ ) led to decreased CAT activity, but did not affect ROS level and glutathione peroxidase activity (Ghosh et al., 2016). In floating aquatic fern (Salvinia natans), exposure to 25nm ZnONPs (1- $50 \mathrm{mg} / \mathrm{L}$ ) showed no effect on plant growth, but led to increased SOD and CAT activities at the highest concentration tested (Hu et al., 2014), suggesting increased oxidative stress responses of fern at $50 \mathrm{mg} \mathrm{Zn/L.} \mathrm{At} 500$ and $750 \mathrm{mg} \mathrm{Zn/kg}$, reduced CAT enzyme activity in stem and leaf were documented for different $\mathrm{Zn}$ compounds in alfalfa (Bandyopadhyay et al., 2015). Our findings showed that MDA and multiple antioxidant biomarkers (SOD, CAT, and POX) were altered in a similar fashion by the $\mathrm{Zn}$ compound type, concentrations, and their interactions (Tables 2, 3; Fig. 3). More specifically, the results showed particle size-, morphology-, and concentration-dependent influence of ZnONPs on MDA and antioxidant biomarkers, including SOD, CAT and POX, in soybean grown for 120 days. Overall, up to $160 \mathrm{mg} \mathrm{Zn/kg} \mathrm{treatments}$ significant protective effects were observed in soybean by all $\mathrm{Zn}$ compound types tested.

As a key antioxidant in the chloroplast, cytosol and mitochondria (Demidchik, 2015), SOD catalyzes the superoxide radical $\left(\mathrm{O}_{2}^{-}\right)$and converts to $\mathrm{H}_{2} \mathrm{O}_{2}$ and $\mathrm{O}_{2}$, thus playing a major role in counteracting oxidative stress (Shekhawat, 2013; Ahmed et al., 2018). The results showed that increased leaf SOD activity $\left(\mathrm{O}_{2}^{-}+2 \mathrm{H}^{+} \rightarrow \mathrm{H}_{2} \mathrm{O}_{2}+\mathrm{O}_{2}\right)$ at $400 \mathrm{mg} \mathrm{Zn/kg} \mathrm{treatments} \mathrm{might} \mathrm{have}$ promoted $\mathrm{H}_{2} \mathrm{O}_{2}$ production as shown in Fig. 3A. However, overall SOD activity was lower up to $160 \mathrm{mg} \mathrm{Zn/kg} \mathrm{treatments} \mathrm{for} \mathrm{all} \mathrm{Zn} \mathrm{compounds} \mathrm{tested} \mathrm{(Fig.} \mathrm{3A).} \mathrm{Superoxide}\left(\mathrm{O}_{2}{ }^{-}\right)$levels were found to increase with $400-3,200 \mathrm{mg} \mathrm{Zn/kg}$ of ZnONPs $(90 \pm 10 \mathrm{~nm})$ and a significant increment in 
SOD activity was documented at the highest dose in maize (Wang et al., 2016a). In Gossypium hirsutum, increased activities of SOD and POX were reported with a subsequent decrease in lipid peroxidation with ZnONPs treatments (Venkatachalam et al., 2017). These results are consistent with our study. Enzymes such as CAT, POX and APX are known to catalytically reduce $\mathrm{H}_{2} \mathrm{O}_{2}$ into water and oxygen within the cell chloroplasts, cytosol, mitochondria, and/or peroxisomes (Anjum et al., 2016). These and other antioxidants may act independently or together via a crosstalk and reduce the extent of oxidative damage and toxicity in plants (Ahmed et al., 2017a and 2017b). CAT, POX, and APX enzymes seem to function concurrently. Herein, low APX activity (Fig. 5A) followed higher CAT and POX activities for ZnONPs and $\mathrm{Zn}^{2+}$ ions (Figs. 4B,C) - a finding consistent with our previous results documented for CuONPs treatments in soybean (YusefiTanha et al., 2020). The overall trend of APX activity upon $\mathrm{Zn}$ compound treatments were reversed compared to MDA accumulation and SOD, CAT and POX responses in soybean leaf (Fig. 5A). Whereas, the scavenging of $\mathrm{H}_{2} \mathrm{O}_{2}$ by the $\mathrm{Zn}$ compounds showed a trend similar to MDA, SOD, CAT and POX responses (Fig. 5B). Further, we documented a clear threshold of $160 \mathrm{mg}$ $\mathrm{Zn} / \mathrm{kg}$ beyond which the responses of soybean upon exposure to all $\mathrm{Zn}$ compounds were found to be negative for all the endpoints measured. Our use of the high purity, same (triclinic) crystal structure and (negative) surface charge for all the three sizes and morphologically different ZnONPs enabled us to specifically test for the size- and morphology-dependent effects of ZnONPs in soybean. Our results showed a significant particle size, morphology and concentration dependent influence of ZnONPs on seed yield, lipid peroxidation, and various antioxidant biomarkers in soil-grown soybean. The findings further suggest unique toxicity of ZnONPs compared to ionic $\mathrm{Zn}^{2+}$ in soybean.

An estimated $50 \%$ of arable soil being used in agriculture may contain reduced amount of soluble $\mathrm{Zn}$, leading to reduced crop yield and poor nutritional quality of grains and derivatives (Moreira et al., 2018). Organic matter is known to influence soil Zn availability to plants with ZnONPs or bulk Zn treatments (Moghaddasi et al., 2017; Medina-Velo et al., 2017; Dimpka et al., 2020). Recently, Dimkpa et al. (2020) documented beneficial effects of $18 \mathrm{~nm}$ ZnONPs on various endpoints (shoot length, plant height, shoot biomass, chlorophyll, grain yield, shoot/grain $\mathrm{Zn}^{2+}$ uptake, grain $\mathrm{Ca}^{2+}$ and $\mathrm{Mg}^{2+}$ uptake) measured in wheat under simulated drought (at $40 \%$ field moisture capacity) and/or with organic manure (cow dung) amendment. At half the concentration, ZnONPs (2.17 mg $\mathrm{ZnO} / \mathrm{kg}$ ) showed similar or greater positive effects than bulk $\mathrm{ZnO}$ treatments (>1000nm powder). These findings are significant in that potentially higher reactivity of ZnONPs may prove more sustainable (on a mass-by-mass basis) compared to bulk Zn fertilization of soil (Dimkpa et al., 
2020). Our findings also suggest the prospect of ZnONPs to be used as a nanofertilizer (up to $160 \mathrm{mg} \mathrm{Zn/kg}$ ) for supplementing Zn element to plants (Singh et al., 2013), reducing oxidative stress, and promoting seed yield. Subsequently, through edible plant parts such as leaves and seeds, $\mathrm{Zn}$ is bioavailable to humans at as high as $70 \%$ while average absorption is about $33 \%$ (Turnlund et al., 1984; Cousins, 1985; FAO/WHO, 2004). As an essential micronutrient, $\mathrm{Zn}$ deficiency has been linked to hypogonadism, anemia, and stunted growth in humans (Roohani et al., 2013); thus, nano-fortification of plants during growth with the required quantity of $\mathrm{Zn}$ (this may depend on soil type) could be a viable concept-one that might be a game changer, particularly, for people who rely on high plant-based diets such as cereals and beans and those who consume less meat (Roohani et al., 2013).

Assessment of the R-squared values for all the endpoints measured showed nonlinear concentration-response curves $\left(\mathrm{R}^{2}<0.65\right)$ (see SI Table S1). Further, our results demonstrated no observed adverse effect level (NOAEL) of $160 \mathrm{mg} / \mathrm{kg}$ for all three different ZnONPs types, including for $\mathrm{Zn}^{2+}$ ions, for all the endpoints measured (see TOC art), except for $\mathrm{H}_{2} \mathrm{O}_{2}$ scavenging (Fig. 5B). The protective effects conferred by ZnONPs up to $160 \mathrm{mg} / \mathrm{kg}$ in soybean can be attributed to the role of $\mathrm{Zn}$ as an essential micronutrient in many enzymes and proteins, which are key for plant growth, development and crop yield (Moreira et al., 2018).

\section{Conclusion}

In summary, our findings demonstrated a significant particle size-, morphology- and concentration-dependent influence of ZnONPs on seed yield, lipid peroxidation, and various antioxidant biomarkers measured in soil-grown soybean. The spherical $38 \mathrm{~nm}$ ZnONPs were the most protective compared to the floral-like 59nm ZnONPs, rod-like $>500 \mathrm{~nm} \mathrm{ZnONPs,} \mathrm{or} \mathrm{Zn}^{2+}$ ions, particularly up to $160 \mathrm{mg} / \mathrm{kg}$. However, at the highest concentration of $400 \mathrm{mg} / \mathrm{kg}$, spherical 38nm ZnONPs elicited the highest oxidative stress responses $\left(\mathrm{H}_{2} \mathrm{O}_{2}\right.$ synthesis, MDA, SOD, CAT, POX) in soybean compared to the other two morphologically different ZnONPs tested. The concentration-response curves for the three types of $\mathrm{ZnONPs}$ and $\mathrm{Zn}^{2+}$ ions were nonlinear for all the endpoints evaluated. Our results also suggest differential nano-specific toxicity of ZnONPs compared to ionic $\mathrm{Zn}^{2+}$ toxicity in soybean. Furthermore, the higher NOAEL value of $160 \mathrm{mg} / \mathrm{kg}$ indicates the potential for using ZnONPs as a nanofertilizer for crops grown in Zn deficient soils to improve crop yield, food quality and address malnutrition, globally. 


\section{Acknowledgements}

This study was conducted at the Department of Agronomy, Shahrekord University, Iran. The authors would like to thank Shahrekord University for providing financial support. LRP gratefully acknowledges funding support from East Carolina University (grant \# 111101 to LRP).

\section{Conflict of Interests}

The authors declare no conflict of interest. 


\section{References}

1. Ahmed, B., Dwivedi, S., Abdin, M.Z., Azam, A., Al-Shaeri, M., Khan, M.S., Saquib, Q., AlKhedhairy, A.A., Musarrat, J., 2017a. Mitochondrial and chromosomal damage induced by oxidative stress in $\mathrm{Zn}^{2+}$ ions, $\mathrm{ZnO}$-bulk and $\mathrm{ZnO}-\mathrm{NPs}$ treated Allium cepa roots. Sci. Rep. 40685 (7), 1-14. https://doi.org/10.1038/srep40685.

2. Ahmed, B., Khan, M.S., Musarrat J., 2018. Toxicity assessment of metal oxide nanopollutants on tomato (Solanum lycopersicon): A study on growth dynamics and plant cell death. Environ. Pollut. 240, 802-816. https://doi.org/10.1016/..envpol.2018.05.015.

3. Ahmed, B., Zaidi, A., Khan, M.S., Rizvi, A., Saif, S., Shahid, M., 2017b. Perspectives of plant growth promoting rhizobacteria in growth enhancement and sustainable production of tomato. Microb. Strat. Veg. Prod. pp 125-149. https://doi.org/10.1007/978-3- 319$\underline{54401-46 .}$.

4. Albersheim, P., Darvill, A., Roberts, K., Sederoff, R., Staehelin. A., 2011. Plant cell walls: from chemistry to biology. Garland Science, New York.

5. Amooaghaie, R., Norouzi, M., Saeri, M., 2016. Impact of zinc and zinc oxide nanoparticles on the physiological and biochemical processes in tomato and wheat. Botany. 95 (5), 441455. https://doi.org/10.1139/cjb-2016-0194.

6. Andreotti, F., Mucha, A.P., Caetano, C., Rodrigues, P., Gomes, C.R., Almeida, C.M.R., 2015. Interactions between salt marsh plants and $\mathrm{Cu}$ nanoparticles - Effects on metal uptake and phytoremediation processes. Ecotoxicol. Environ. Saf. 120, 303-309. http://dx.doi.org/10.1016/j.ecoenv.2015.06.017.

7. Bandyopadhyay, S., Plascencia-Villa, G., Mukherjee, A., Rico, C.M., José-Yacamán, M., Peralta-Videa, J.R., Gardea-Torresdey, J.L., 2015. Comparative phytotoxicity of ZnO NPs, bulk $\mathrm{ZnO}$, and ionic zinc onto the alfalfa plants symbiotically associated with Sinorhizobium meliloti in soil. Sci. Total Environ. 515-516, 60-69. http://doi.org/10.1016/i.scitotenv.2015.02.014.

8. Barker, A.V., Pilbeam D.J., 2015. Handbook of plant nutrition. CRC press is an imprint of Taylor \& Francis group. 2nd edition, pp, 537-567.

9. Benkeblia, N., 2005. Free-radical scavenging capacity and antioxidant properties of some selected onions (Allium cepa L.) and garlic (Allium sativum L.) extracts. Braz. Arch. Biol. Technol. 48 (5), 753-759. http://doi.org/10.1590/S1516-89132005000600011.

10. Cao, Z., Stowers, C., Rossi, L., Zhang, W., Lombardini, L., Ma, X., 2017. Physiological effects of cerium oxide nanoparticles on the photosynthesis and water use efficiency of soybean (Glycine max L. Merr). Environ. Sci. Nano. 4, 1086-1094. http://doi.org/10.1039/C7EN00015D.

11. Cousins RJ. Absorption, transport, and hepatic metabolism of copper and zinc: Special reference to metallothionein and ceruloplasmin. Physiol Rev. 1985;65:238-309. 
12. Das, K., Roychoudhury, A., 2014. Reactive oxygen species (ROS) and response of antioxidants as ROS-scavengers during environmental stress in plants. Front. Environ. Sci. 2, 1-12. https://doi.org/10.3389/fenvs.2014.00053.

13. Del Rio, L.A., Sandalio, L.M., Corpas, F.J., Palma, J.M., Barroso, J.B., 2006. Reactive oxygen species and reactive nitrogen species in peroxisomes, production, scavenging and role in cell signaling. Plant Physiol. 141 (2), 330-335. https://doi.org/10.1104/pp.106.078204.

14. Demidchik, V., 2015. Mechanisms of oxidative stress in plants: from classical chemistry to cell biology. Environ. Exp. Bot. 109, 212-228. https://doi.org/10.1016/i.envexpbot.2014.06.021.

15. Deng, Y.Q., White, J.C., Xing, B.S., 2014. Interactions between engineered nanomaterials and agricultural crops: implications for food safety. J. Zhejiang Univ-Sci. A. 15 (8), 552-572. https://doi.org/10.1631/jzus.A1400165.

16. Deng, Y., Eitzer, B., White, J.C., Xing, B., 2017. Impact of multiwall carbon nanotubes on the accumulation and distribution of carbamazepine in collard greens (Brassica oleracea). Environ. Sci. Nano. 4, 149-159. https://doi.org/10.1039/C6EN00419A.

17. Dietz, K.J., Herth, S., 2011. Plant nanotoxicology. Trends Plant Sci. 16 (11), 582-589. https://doi.org/10.1016/j.tplants.2011.08.003.

18. Dimkpa, C., Bindraban, P., 2018. Nanofertilizers: new products for the industry? J. Agric. Food Chem. 66 (26), 6462-6473. https://doi.org/10.1021/acs.jafc.7b02150.

19. Dimkpa, C., Bindraban, P., Fugice, J., Agyin-Birikorang, S., Singh, U., Hellums, D., 2017a. Composite micronutrient nanoparticles and salts decrease drought stress in soybean. Agron. Sustain. Dev. 37, 5. https://doi.org/10.1007/s13593-016-0412-8.

20. Dimkpa, C.O., McLean, J.E., Britt, D.W., Anderson, A.J., 2015. Nano-CuO and interaction with nano-ZnO or soil bacterium provide evidence for the interference of nanoparticles in metal nutrition of plants. Ecotoxicol. 24 (1), 119-129. https://doi.org/10.1007/s10646-0141364-X.

21. Dimkpa, C.O., McLean, J.E., Latta, D.E., Manangon, E., Britt, D.W., Johnson, W.P., Boyanov, M.I., Anderson, A.J., 2012. CuO and ZnO nanoparticles: phytotoxicity, metal speciation, and induction of oxidative stress in sand-grown wheat. J. Nanopart. Res. 14, 1125. https://doi.org/10.1007/s11051-012-1125-9.

22. Dimkpa, C.O., Singh, U, Bindrabana, P.S., Elmer, W.H., Gardea-Torresdey, J.L., White, J.C., 2019. Zinc oxide nanoparticles alleviate drought-induced alterations in sorghum performance, nutrient acquisition, and grain fortification. Sci. Total Environ. 688, 926-934. https://doi.org/10.1016/i.scitotenv.2019.06.392.

23. Dimkpa, C.O., White, J.C., Elmer, W.H., Gardea-Torresdey, J., 2017b. Nanoparticle and ionic Zn promote nutrient loading of sorghum grain under low NPK fertilization. J. Agric. Food Chem. 65 (39), 8552-8559. https://doi.org/10.1021/acs.jafc.7b02961. 
24. Dimkpa, C.O., Singh, U., Bindraban, P.S., Elmer, W.H., Gardea-Torresdey, J.L., White, J.C., 2018. Exposure to weathered and fresh nanoparticle and ionic $\mathrm{Zn}$ in soil promotes grain yield and modulates nutrient acquisition in wheat (Triticum aestivum L.). J. Agric. Food Chem. 66 (37), 9645-9656. https://doi.org/10.1021/acs.jafc.8b03840.

25. Dimkpa, C.O., Andrews, J., Sanabria, J., Bindraban, P.S., Singh, U., Elmer, W.H., Gardea-Torresdey, J.L., White, J.C. Interactive effects of drought, organic fertilizer, and zinc oxide nanoscale and bulk particles on wheat performance and grain nutrient accumulation. Science of The Total Environment Volume 722, 20 June 2020, 137808. https://doi.org/10.1016/i.scitotenv.2020.137808.

26. Du, W., Sun, Y., Ji, R., Zhu, J., Wu, J., Guo, H., 2011. $\mathrm{TiO}_{2}$ and $\mathrm{ZnO}$ nanoparticles negatively affect wheat growth and soil enzyme activities in agricultural soil. J. Environ. Monitor. 13, 822-828. https://doi.org/10.1039/COEM00611D.

27. Du, W., Tan, W., Peralta-Videa, J.R., Gardea-Torresdey, J.L., Ji, R., Yin, Y., Guo, H., 2017. Interaction of metal oxide nanoparticles with higher terrestrial plants: physiological and biochemical aspects. Plant Physiol. Biochem. 110, 210-225. https://doi.org/10.1016/i.plaphy.2016.04.024.

28. Du, W., Yang, J., Peng, Q., Liang, X., Mao, H., 2019. Comparison study of zinc nanoparticles and zinc sulphate on wheat growth: From toxicity and zinc biofortification. Chemosphere. 227, 109-116. https://doi.org/10.1016/j.chemosphere.2019.03.168.

29. Faizan, M., Faraz, A., Yusuf, M., Khan, S.T., Hayat, S., 2018. Zinc oxide nanoparticlemediated changes in photosynthetic efficiency and antioxidant system of tomato plants. Photosynthetica. 56 (2), 678-686. https://doi.org/10.1007/s11099-017-0717-0.

30. FAO/WHO. Expert Consultation on Human Vitamin and Mineral Requirements, Vitamin and mineral requirements in human nutrition: Report of joint FAO/WHO expert consolation; 2nd ed. Bangkok, Thailand: 2004. p. 341.

31. Food and Agriculture Organization of the United Nations, 2019. http://www.fao.org/ faostat/en/\#data/QC.

32. Gaschler, M.M., Stockwell, B.R., 2017. Lipid peroxidation in cell death. Biochem. Biophys. Res. Commun. 482 (3), 419-425. https://doi.org/10.1016/..bbrc.2016.10.086.

33. Ghasemi Siani, N., Fallah, S., Pokhrel, L.R., Rostamnejadi, A., 2017. Natural amelioration of

zinc oxide nanoparticles toxicity in fenugreek (Trigonella foenum-gracum) by arbuscular mycorrhizal (Glomus intraradices) secretion of glomalin. Plant Physiol. Biochem. 112, 227-238. https://doi.org/10.1016/j.plaphy.2017.01.001.

34. Getnet, Z., Husen, A., Fetene, M., Yemata, G., 2015. Growth, water status, physiological, biochemical and yield response of stay green sorghum (Sorghum bicolor (L.) moench) varieties-a field trial under drought-prone area in Amhara Regional State, Ethiopia. J. Agron. 14 (4), 188-202. https://doi.org/10.3923/ja.2015.188.202.

35. Ghosh, M., Jana, A., Sinha, S., Jothiramajayam, M., Nag, A., Chakraborty, A., Mukherjee, A., Mukherjee, A., 2016. Effects of ZnO nanoparticles in plants: cytotoxicity, genotoxicity, 
deregulation of antioxidant defenses, and cell-cycle arrest. Mutat. Res. Genet. Toxicol. Environ. Mutagen. 807, 25-32. https://doi.org/10.1016/j.mrgentox.2016.07.006.

36. Gill, S.S., Tuteja, N., 2010. Reactive oxygen species and antioxidant machinery in abiotic stress tolerance in crop plants. Plant Physiol. Biochem. 48 (12), 909-930. https://doi.org/10.1016/j.plaphy.2010.08.016.

37. Hatami, M., Kariman, K., Ghorbanpour, M., 2016. Engineered nanomaterial-mediated changes in the metabolism of terrestrial plants. Sci. Total Environ. 571, 275-291. https://doi.org/10.1016/i.scitotenv.2016.07.184.

38. Heath, R.L., Packer, L., 1968. Photoperoxidation in isolated chloroplast: i. Kinetics and stoichionetry of fatty acid peroxidation. Arch. Biochem. Biophys. 125 (1), 189-198. https://doi.org/10.1016/0003-9861(68)90654-1.

39. Hemantaranjan, A., Garg, O.K., 2015. Introduction of nitrogen-fixing nodules through iron and zinc fertilization in the nonnodule-forming French bean (Phaseolus vulgaris L.). J. Plant Nutr. 9 (3-7), 281-288. http://dx.doi.org/10.1080/01904168609363444.

40. Hernandez-Viezcas, J.A., Castillo-Michel, H., Servin, A.D., Peralta-Videa, J.R., GardeaTorresdey, J.L., 2011. Spectroscopic verification of zinc absorption and distribution in the desert plant Prosopis juliflora-velutina (velvet mesquite) treated with $\mathrm{ZnO}$ nanoparticles, Chem. Eng. J. 170: 346-352. https://doi.org/10.1016/i.cej.2010.12.021.

41. Hong, J., Rico, C., Zhao, L., Adeleye, A.S., Keller, A.A., Peralta-Videa, J.R., GardeaTorresdey, J.L., 2015. Toxic effects of copper-based nanoparticles or compounds to lettuce (Lactuca sativa) and alfalfa (Medicago sativa). Environ. Sci.: Processes Impacts. 17, 177-185. https://doi.org/10.1039/C4EM00551A.

42. Hou, J., Wu, Y., Li, X., Wei, B., Li, S., Wang, X., 2018. Toxic effects of different types of zinc oxide nanoparticles on algae, plants, invertebrates, vertebrates and microorganisms. Chemosphere. 193, 852-860. https://doi.org/10.1016/..chemosphere.2017.11.077.

43. Hu, C., Liu, X., Li, X., Zhao, Y., 2014. Evaluation of growth and biochemical indicators of Salvinia natans exposed to zinc oxide nanoparticles and zinc accumulation in plants. Environ. Sci. Pollut. Res. 21 (1), 732-739. https://doi.org/10.1007/s11356-013-1970-9.

44. Impa, S.M., Morete, M.J., Ismail, A.M., Schulin, R., Johnson-Beebout, S.E., 2013. Zn uptake, translocation and grain $\mathrm{Zn}$ loading in rice (Oryza sativa L.) genotypes selected for $\mathrm{Zn}$ deficiency tolerance and high grain Zn. J. Exp. Bot. 64 (10), 2739-2751. https://doi.org/10.1093/jxb/ert118.

45. Jahan, S., Binti Alias, Y., Abu Bakar, A.F.B., Bin Yusoff, I., 2018. Toxicity evaluation of $\mathrm{ZnO}$ and $\mathrm{TiO}_{2}$ nanomaterials in hydroponic red bean (Vigna angularis) plant: physiology, biochemistry and kinetic transport. J. Environ. Sci. 72, 140-152. https://doi.org/10.1016/.j.jes.2017.12.022.

46. Kanchana, P., Lakshmi Santha, M., Dilip Raja, K., 2016. A review on Glycine max (L.) merr. (soybean). World J. Pharm. Pharm. Sci. 5 (1), 356-371. 
47. Kim, S., Lee, S., Lee, I., 2012. Alteration of phytotoxicity and oxidant stress potential by metal oxide nanoparticles in Cucumis sativus. Water Air Soil Poll. 223 (5), 2799-2806. https://doi.org/10.1007/s11270-011-1067-3.

48. Kobraee, S., Shamsi, K., 2015. Relationships between oil, protein and dry matter in soybean seed with some of micronutrients fertilization. Res. J. Soil Biol. 7 (2), 56-63. https://doi.org/10.3923/risb.2015.56.63.

49. Kranjc, E., Mazej, D., Regvar, M., Drobne, D., Remškar, M., 2018. Foliar surface free energy a ects platinum nanoparticle adhesion, uptake, and translocation from leaves to roots in arugula and escarole. Environ. Sci. Nano. 5, 520-532. https://doi.org/10.1039/C7EN00887B.

50. Kumari, M., Khan, S.S., Pakrashi, S., Mukherjee, A., Chandrasekaran, N., 2011. Cytogenetic and genotoxic effects of zinc oxide nanoparticles on root cells of Allium cepa. J. Hazard Mater. 190 (1-3), 613-621. https://doi.org/10.1016/j.jhazmat.2011.03.095.

51. Kurutas, E.B. 2016. The importance of antioxidants which play the role in cellular response against oxidative/nitrosative stress: current state. Nutrition journal, 15(1), 71. doi:10.1186/s12937-016-0186-5.

52. Lee, S., Kim, S., Kim, S., Lee, I., 2013. Assessment of phytotoxicity of ZnO NPs on a medicinal plant Fagopyrum esculentum. Environ Sci Pollut Res 20 (2), 848-854. https://doi.org/10.1007/s11356-012-1069-8.

53. Lee, C.W., Mahendra, S., Zodrow, K., Li, D., Tsai, Y.C., Braam, J., Alvarez, P.J., 2010. Developmental phytotoxicity of metal oxide nanoparticles to Arabidopsis thaliana. Environ. Technol. Chem. 29 (3), 669-675. https://doi.org/10.1002/etc.58.

54. Li, Q.T., Lu, X., Song, Q.X., Chen, H.W., Wei, W., Tao, J.J., Bian, X.H., Shen, M., Ma, B., Zhang, W.K., Bi, Y.D., Li, W., Lai, Y.C., Lam, S.M., Shui, G.H., Chen, S.Y., Zhang, J.S., 2017. Selection for a zinc-finger protein contributes to seed oil increase during soybean domestication. Plant Physiol. 173 (4), 2208-2224. https://doi.org/10.1104/pp.16.01610.

55. Lin, D., Xing, B., 2008. Root uptake and phytotoxicity of ZnO nanoparticles. Environ. Sci. Technol. 42 (15), 5580-5585. https://doi.org/10.1021/es800422x.

56. Lin, S., Reppert, J., Hu, Q., Hudson, J.S., Reid, M.L., Ratnikova, T.A., Rao, A.M., Luo, H., Ke, P.C., 2009. Uptake, translocation, and transmission of carbon nanomaterials in rice plants.

Small: nano micro 5 (10), 1128-1132. https://doi.org/10.1002/smll.200801556.

57. Liu, X., Wang, F., Shi, Z., Tong, R., Shi, X., 2015. Bioavailability of Zn in ZnO nanoparticlespiked soil and the implications to maize plants. J Nanopart Res. 17, 175. https://doi.org/10.1007/s11051-015-2989-2.

58. Lopez-Moreno, M.L., de la Rosa, G., Hernandez-Viezcas, J.A., Castillo-Michel, H., Botez, C.E.,

59. Peralta-Videa, J.R., Gardea-Torresdey, J.L., 2010. Evidence of the differential biotransformation and genotoxicity of $\mathrm{ZnO}$ and $\mathrm{CeO}_{2}$ nanoparticles on soybean (Glycine 
max) plants. Environ. Sci. Technol. $44 \quad$ (19), 7315-7320. https://doi.org/10.1021/es903891g.

60. Ma, X., Geiser-Lee, J., Deng, Y., Kolmakov, A., 2010. Interactions between engineered nanoparticles (ENPs) and plants: phytotoxicity uptake and accumulation. Sci. Total Environ. 408 (16), 3053-3061. https://doi.org/10.1016/j.scitotenv.2010.03.031.

61. Ma, C.X., White, J.C., Dhankher, O.P., Xing, B., 2015. Metal-based nanotoxicity and detoxification pathways in higher plants. Environ. Sci. Technol. 49 (12), 7109-7122. https://doi.org/10.1021/acs.est.5b00685.

62. MacAdam, J.W., Nelson, C.J., Sharp, R.E., 1992. Peroxidase Activity in the leaf elongation zone of tallfescue. Plant Physiol. 99, 872-878. https://doi.org/10.1104/pp.99.3.872.

63. Mahajan, P., Dhoke, S.K., Khanna, A.S., 2011. Effect of nano-ZnO particle suspension on growth of mung (Vigna radiata) and gram (Cicer arietinum) seedlings using plant agar method. J. Nanotechnol. 1-7. http://dx.doi.org/10.1155/2011/696535.

64. Malea, P., Charitonidou, K., Sperdouli, I., Mylona, Z., Moustakas, M., 2019. Zinc uptake, photosynthetic effciency and oxidative stress in the seagrass Cymodocea nodosa exposed to ZnO nanoparticles. Materials. 12 (2101), 1-15. https://doi.org/10.3390/ma12132101.

65. Masarovičová, E., Král'ová, K., 2013. Metal nanoparticles and plants. Ecol. Chem. Eng. S. 20 (1), 9-22. https://doi: 10.2478/eces-2013-0001.

66. Medina-Velo, I.A., Dominguez, O.E., Ochoa, L., Barrios, A.C., Hernández-Viezcas, J.A., White, J.C., Peralta-Videa, A.R., Gardea-Torresdey, J.L., 2017. Nutritional quality of bean seeds harvested from plants grown in different soils amended with coated and uncoated zinc oxide nanomaterials. Environ. Sci., Nano 4, 2336-2347.

67. Moreira, A., Moraes, L.A.C., dos Reis, A.R. Chapter 5 - The Molecular Genetics of Zinc Uptake and Utilization Efficiency in Crop Plants. In: Plant Micronutrient Use Efficiency, Editor(s): Mohammad Anwar Hossain, Takehiro Kamiya, David J. Burritt, Lam-Son Phan Tran, Toru Fujiwara, Academic Press, 2018, Pages 87-108, ISBN 9780128121047, https://doi.org/10.1016/B978-0-12-812104-7.00006-X.

68. Moghaddasi, S., Fotovat, A., Khoshgoftarmanesh, A.H., Karimzadeh, F., Khazaei, H.R., Khorassani, R., 2017. Bioavailability of coated and uncoated $\mathrm{ZnO}$ nanoparticles to cucumber in soil with or without organic matter. Ecotoxicol. Environ. Safety 144, 543551.

69. Moghaddasi, S., Fotovat, A., Karimzadeh, F., Khazaei, H.R., Khorassani, R., Lakzian, A., 2017. Effects of coated and non-coated $\mathrm{ZnO}$ nano particles on cucumber seedlings grown in gel chamber. Arch. Agron. Soil Sci. 63 (8), 1108-1120. https://doi.org/10.1080/03650340.2016.1256475.

70. Moustakas, M., Malea, P., Haritonidou, K., Sperdouli, I., 2017. Copper bioaccumulation, photosystem II functioning and oxidative stress in the seagrass Cymodocea nodosa exposed to copper oxide nanoparticles. Environ. Sci. Pollut. Res. 24 (19),16007-16018. https://doi.org/10.1007/s11356-017-9174-3. 
71. Mukherjee, A., Peralta-Videa, J.R., Bandyopadhyay, S., Rico, C.M., Zhao, L., GardeaTorresdey, J.L., 2014a. Physiological effects of nanoparticulate ZnO in green peas (Pisum sativum L.) cultivated in soil. Metallomics. 6, 132-138. https://doi.org/10.1039/C3MT00064H.

72. Mukherjee, A., Pokhrel, S., Bandyopadhyay, S., Madler, L., Peralta-Videa, J.R., GardeaTorresdey, J.L., 2014b. A soil mediated phyto-toxicological study of iron doped zinc oxide nanoparticles (Fe@ZnO) in green peas (Pisum sativum L.). Chem. Eng. J. 258, 394-401. https://doi.org/10.1016/j.cej.2014.06.112.

73. Mukherjee, A., Sun, Y., Morelius, E., Tamez, C., Bandyopadhyay, S., Niu, G., White, J.C., Peralta-Videa, J.R., Gardea-Torresdey, J.L., 2016. Differential toxicity of bare and hybrid $\mathrm{ZnO}$ nanoparticles in green pea (Pisum sativum L.): a life cycle study. Front. Plant. Sci. 6, 1242. https://doi.org/10.3389/fpls.2015.01242.

74. Nag, S., Saha, K., Choudhuri, M.A., 2000. A rapid and sensitive assay method for measuring amine oxidase based on hydrogen peroxide-titanium complex formation. Plant Sci. 157 (2), 157-163. https://doi.org/10.1016/S0168-9452(00)00281-8.

75. Nakasato, D.Y., Pereira, A.E., Oliveira, J.L., Oliveira, H.C. Fraceto, L.F., 2017. Evaluation of the effects of polymeric chitosan/tripolyphosphate and solid lipid nanoparticles on germination of Zea mays, Brassica rapa and Pisum sativum. Ecotoxic. Environ. Saf. 142, 369-374. https://doi.org/10.1016/j.ecoenv.2017.04.033.

76. Narwal, S.S., Bogatek, R., Zagdanska, B.M., Sampietro, D.A., Vattuone, M.A., 2009. Plant Biochemistry. Studium Press LLC, Texas.

77. Navarro, E., Baun, A., Behra, R., Hartmann, N.B., Filser, J., Miao, A.J., Quigg, A., Santschi, P.H., Sigg, L., 2008. Environmental behavior and ecotoxicity of engineerednanoparticles to algae, plants, and fungi. Ecotoxicol. 17 (5), 372-386. https://doi.org/10.1007/s10646-008-0214-0.

78. Nuruzzaman, M., Rahman, M.M., Liu, Y., Naidu, R., 2016. Nanoencapsulation, nanoguard for pesticides: a new window for safe application. J. Agric. Food Chem. 64 (7), 14471483. https://doi.org/10.1021/acs.jafc.5b05214.

79. Ogunkunle, C.O., Jimoh, M.A., Asogwa, N.T., Viswanathan, K., Vishwakarma, V., Fatoba, P.O., 2018. Effects of manufactured nano-copper on copper uptake, bioaccumulation and enzyme activities in cowpea grown on soil substrate. Ecotoxicol. Environ. Saf. 155, 86-93. https://doi.org/10.1016/j.ecoenv.2018.02.070.

80. Ozyigit, I.I., Filiz, E., Vatansever, R., Kurtoglu, K.Y., Koc, I., Oztürk, M.X., Anjum, N.A., 2016. Identification and comparative analysis of $\mathrm{H}_{2} \mathrm{O}_{2}$-scavenging enzymes (ascorbate peroxidase and glutathione peroxidase) in selected plants employing bioinformatics approaches. Front. Plant Sci. 7, 301. https://doi.org/10.3389/fpls.2016.00301.

81. Pagano, L., Pasquali, F., Majumdar, S., Torre-Roche, R.D., Zuverza-Mena, N., Villani, M., Zappettini, A., Marra, R.E., Isch, S.M., Marmiroli, M., Maestri, E., Dhankher, O.P., White, J.C., Marmiroli, N., 2017. Exposure of Cucurbita pepo to binary combinations of engineered nanomaterials: physiological and molecular response. Environ. Sci. Nano. 4, 1579-1590. https://doi.org/10.1039/C7EN00219J. 
82. Pokhrel, L.P., Silva, T., Dubey, B., El Badawy, A.M., Tolaymat, T.M., Scheuerman, P.R., 2012. Rapid screening of aquatic toxicity of several metal-based nanoparticles using the MetPLATE ${ }^{\mathrm{TM}}$ bioassay. Sci. Total Environ. 426, 414-422. https://doi.org/10.1016/i.scitotenv.2012.03.049.

83. Del Real, A.E.P., Vidal, V., Carrière, M., Castillo-Michel, H., Levard, C., Chaurand, P., Sarret, G., 2017. Silver nanoparticles and wheat roots: a complex interplay. Environ. Sci. Technol. 51 (10), 5774-5782. https://doi.org/10.1021/acs.est.7b00422.

84. Priester, J.H., Ge, Y., Mielke, R.E., Horst, A.M., Moritz, S.C., Espinosa, K., Gelb, J., Walker, S.L., Nisbet, R.M., An, Y.J., 2012. Soybean susceptibility to manufactured nanomaterials with evidence for food quality and soil fertility interruption. Proc. Natl. Acad. Sci. USA. 109 (37), 2451-2456. https://doi.org/10.1073/pnas.1205431109.

85. Rajput, V., Minkina, T., Fedorenko, A., Sushkova, S., Mandzhieva, S., Lysenko, V., Duplii, N., Fedorenko, G., Dvadnenko, K., Ghazaryan, K., 2018. Toxicity of copper oxide nanoparticles on spring barley (Hordeum sativum distichum). Sci. Total Environ. 645, 1103-1113. https://doi.org/10.1016/j.scitotenv.2018.07.211.

86. Raliya, R., Tarafdar, J.C., Biswas, P., 2016. Enhancing the mobilization of native phosphorus in mung bean rhizosphere using $\mathrm{ZnO}$ nanoparticles synthesized by fungi. J. Agric. Food Chem. 64 (16), 3111-3118. https://doi.org/10.1021/acs.jafc.5b05224.

87. Reddy, P.V., Hernandezviezcas, J.A., Peraltavidea, J.R., Gardeatorresdey, J.L., 2016. Lessons learned: are engineered nanomaterials toxic to terrestrial plants? Sci. Total Environ. 568, 470-479. https://doi.org/10.1016/j.scitotenv.2016.06.042.

88. Rizwan, M., Ali, S., Qayyum, M.F., Ok, Y.S., Adrees, M., Ibrahim, M., Zia-ur-Rehman, M., Farid, M., Abbas, F., 2017. Effect of metal and metal oxide nanoparticles on growth and physiology of globally important food crops: a critical review. J. Hazard. Mater. 322 (A), 216. https://doi.org/10.1016/j.jhazmat.2016.05.061.

89. Roohani, N., Hurrell, R., Kelishadi, R., \& Schulin, R. (2013). Zinc and its importance for human health: An integrative review. Journal of research in medical sciences: the official journal of Isfahan University of Medical Sciences, 18(2), 144-157.

90. Rostamnejadi, A., Venkatesan, M., Salamati, H., Ackland, K., Gholizadeh, H., Kameli, P., Coey, J.M.D., 2017. Magnetic properties, exchange bias and memory effects in coreshell superparamagnetic nanoparticles of La0.67Sr0.33MnO3. J. Appl. Phys. 121, 173902. https://doi.org/10.1063/1.4982893.

91. Santos, A.R., Miguel, A.S., Tomaz, L., Malhó, R., Maycock, C., Vaz Patto, M.C., Fevereiro, P., Oliva, A., 2010. The impact of CdSe/ZnS quantum dots in cells of Medicago sativa in suspension culture. J. Nanobiotechnol. 8 (1), 24. https://doi.org/10.1186/1477-3155-8-24.

92. Schwab, F., Zhai, G., Kern, M., Turner, A., Schnoor, J.L., Wiesner, M.R., 2016. Barriers, pathways and processes for uptake, translocation and accumulation of nanomaterials in $\begin{array}{llll}\text { plants-critical } & \text { review. } & \text { 257-278. }\end{array}$ https://doi.org/10.3109/17435390.2015.1048326. 
93. Shekhawat, S.G.S., 2013. Toxicity of $\mathrm{ZnO}$ engineered nanoparticles and evaluation of effect on growth, metabolism and tissue specific accumulation in Brassica juncea. J. Environ. Chem. Eng. 2(1), 105-114. http://dx.doi.org/doi:10.1016/.j.jece.2013.11.029.

94. Siddiqi, K.S., Husen, A., 2017. Plant response to engineered metal oxide nanoparticles. Nanoscale Res. Lett. 12 (92), 1-18. https://doi.org/10.1186/s11671-017-1861-y.

95. Singh, A., Singh, N.B., Afzal, S., Singh, T., Hussain, I., 2018. Zinc oxide nanoparticles: a review of their biological synthesis, antimicrobial activity, uptake, translocation and biotransformation in plants. J. Mater. Sci. 53 (1), 185-201. https://doi.org/10.1007/s10853017-1544-1.

96. Singh, N., Amist, N., Yadav, K., Singh, D., Pandey, J., Singh, S., 2013. Zinc oxide nanoparticles as fertilizer for the germination, growth and metabolism of vegetable crops. J. Nanoeng. Nanomanuf. 3 (4), 353-64. https://doi.org/10.1166/jnan.2013.1156.

97. Słomka, A., Libik-Konieczny, M., Kuta, E., Miszalski, Z., 2008. Metalliferous and nonmetalliferous populations of Viola tricolor represent similar mode of antioxidative $\begin{array}{llllll}\text { response. } & J & \text { Plant } & \text { Physiol. } & 165 & \text { (15), }\end{array}$ https://doi.org/10.1016/j.jplph.2007.11.004.

98. Srivastava, G., Das, C.K., Das, A., Singh, S.K., Roy, M., Kim, H., Sethy, N., Kumar, A., Sharma, R.K., Singh, S.K., 2014. Seed treatment with iron pyrite $\left(\mathrm{FeS}_{2}\right)$ nanoparticles increases the production of spinach. RSC Adv. 4, 58495-58504. https://doi.org/10.1039/C4RA06861K.

99. The National Nanotechnology Initiative: Research and Development Leading to a Revolution in Technology and Industry, Supplement to the President's FY 2006, March 21, 2005. Available at: https://www.nano.gov/2006-Budget-Supplement.

100. Tsonev, T., Lidon, F.J.C., 2012. Zinc in plants- an overview. Emir. J. Food Agric. 24 (4), 322-333.

101. Turnlund JR, King JC, Keyes WR, Gong B, Michel MC. A stable isotope study of zinc absorption in young men: Effects of phytate and alpha-cellulose. Am $\mathrm{J}$ Clin Nutr. 1984;40:1071-7.

102. Venkatachalam, P., Priyanka, N., Manikandan, K., Ganeshbabu, I., Indiraarulselvi, P., Geetha, N., Muralikrishna, K., Bhattacharya, R., Tiwari, M., Sharma, N., Sahi, S.V., 2017. Enhanced plant growth promoting role of phycomolecules coated zinc oxide nanoparticles with P supplementation in cotton (Gossypium hirsutum L.). Plant Physiol. Biochem. 110, 118-127. https://doi.org/10.1016/i.plaphy.2016.09.004.

103. Wang, F., Liu, X., Shi, Z., Tong, R., Adams, C.A., Shi, X., 2016a. Arbuscular mycorrhizae alleviate negative effects of zinc oxide nanoparticle and zinc accumulation in maize plantsa soil microcosm experiment. Chemosphere. 147, 88-97. https://doi.org/10.1016/j.chemosphere.2015.12.076.

104. Wang, P., Menzies, N.W., Lombi, E., McKenna, B.A., Johannessen, B., Glover, C.J., Kappen, P., Kopittke, P.M., 2013. Fate of ZnO nanoparticles in soils and cowpea (Vigna 
$\begin{array}{lllll}\text { unguiculata). } & \text { Environ. } & \text { Sci. } & \text { Technol. } 47 & \text { (23), }\end{array}$ https://doi.org/10.1021/es403466p.

105. Wang, X.P., Li, Q.Q., Pei, Z.M., Wang, S.C., 2018. Effects of zinc oxide nanoparticles on the growth, photosynthetic traits, and antioxidative enzymes in tomato plants. Biol. Plant. 62 (4), 801-808. https://doi.org/10.1007/s10535-018-0813-4.

106. Wang, Y., Sun, C., Zhao, X., Cui, B., Zeng, Z., Wang, A., Liu, G., Cui, H., 2016b. The application of nano- $\mathrm{TiO}_{2}$ photo semiconductors in agriculture. Nanoscale Res. Lett. 11, 529. https://doi.org/10.1186/s11671-016-1721-1.

107. Watson, J. L., Fang, T., Dimkpa, C.O., Britt, D.W., McLean, J.E., Jacobson, A., Anderson, A.J., 2015. The phytotoxicity of $\mathrm{ZnO}$ nanoparticles on wheat varies with soil properties. Biometals. 28 (1), 101-112. https://doi.org/10.1007/s10534-014-9806-8.

108. White, J.C., Gardea-Torresdey, J.L., 2018. Achieving food security through the very small. Nat. Nanotechnol. 13, 627-629. https://doi.org/10.1038/s41565-018-0223-y.

109. Xiong, T., Dumat, C., Dappe, V., Vezin, H., Schreck, E., Shahid, M., Pierart, A., Sobanska, S., 2017. Copper oxide nanoparticle foliar uptake, phytotoxicity, and consequences for sustainable urban agriculture. Environ. Sci. Technol. 51 (9), 5242-5251. https://doi.org/10.1021/acs.est.6b05546.

110. Yruela, I., 2015. A handbook of plant nutrition-2nd edition. Estación Experimental de Aula Dei, Consejo Superior de Investigaciones Científicas (EEAD-CSIC), Avda. Montañana 1005, 50059-Zaragoza, Spain.

111. Yusefi-Tanha, E., Fallah, S., Rostamnejadi, A., Pokhrel, L.R., 2020. Particle size and concentration dependent toxicity of copper oxide nanoparticles (CuONPs) on seed yield and antioxidant defense system in soil grown soybean (Glycine max cv. Kowsar). Sci. Total Environ. 715, 136994. https://doi.org/10.1016/i.scitotenv.2020.136994.

112. Zafar, H., Ali, A., Ali, J.S., Haq, I.U., Zia, M., 2016. Effect of ZnO nanoparticles on Brassica nigra seedlings and stem explants: growth dynamics and antioxidative response. Front. Plant Sci. 7, 535. https://doi.org/10.3389/fpls.2016.00535.

113. Zandi, S., Kameli, P., Salamati, H., Ahmadvand, H., Hakimi, M., 2011. Microstructure and optical properties of $\mathrm{ZnO}$ nanoparticles prepared by a simple method. Phys. B 406, 32153218.

114. Zhang, T., Sun, H., Lv, Z., Cui, L., Mao, H., Kopittke, P.M., 2018. Using synchrotron-based approaches to examine the foliar application of $\mathrm{ZnSO}_{4}$ and $\mathrm{ZnO}$ nanoparticles for fieldgrown winter wheat. J. Agr. Food Chem. 66 (11), 2572-2579. https://doi.org/10.1021/acs.jafc. $7 b 04153$.

115. Zhao, L., Hernandez-Viezcas, J.A., Peralta-Videa, J.R., Bandyopadhyay, S., Peng, B., Munoz, B., Keller, A.A., Gardea-Torresdey, J.L., 2013. ZnO nanoparticle fate in soil and zinc bioaccumulation in corn plants (Zea mays) influenced by alginate. Environ. Sci.: Process Impacts. 15, 260-266. https://doi.org/10.1039/C2EM30610G. 
116. Zhu, H., Han, J., Xiao, J.Q., Jin, Y., 2008. Uptake, translocation, and accumulation of manufactured iron oxide nanoparticles by pumpkin plants. J. Environ. Monit. 10 (6), 713-717. https://doi.org/10.1039/B805998E.

117. Zulfiqar, F., Navarro, M., Ashraf, M., Akram, N.A., Munné-Bosch, S., 2019. Nanofertilizer use for sustainable agriculture: Advantages and limitations. Plant Sci. 289, 110270. https://doi.org/10.1016/i.plantsci.2019.110270.

118. Zuverza-Mena, N., Martínez-Fernández, D., Du, W., Hernandez-Viezcas, J.A., BonillaBird, N., López-Moreno, M.L., Komárek, M., Peralta-Videa, J.R., Gardea-Torresdey, J.L., 2017. Exposure of engineered nanomaterials to plants: insights into the physiological and biochemical responses-a review. Plant Physiol. Biochem. 110, 236-264. https://doi.org/10.1016/j.plaphy.2016.05.037. 


\section{Figures and Tables}
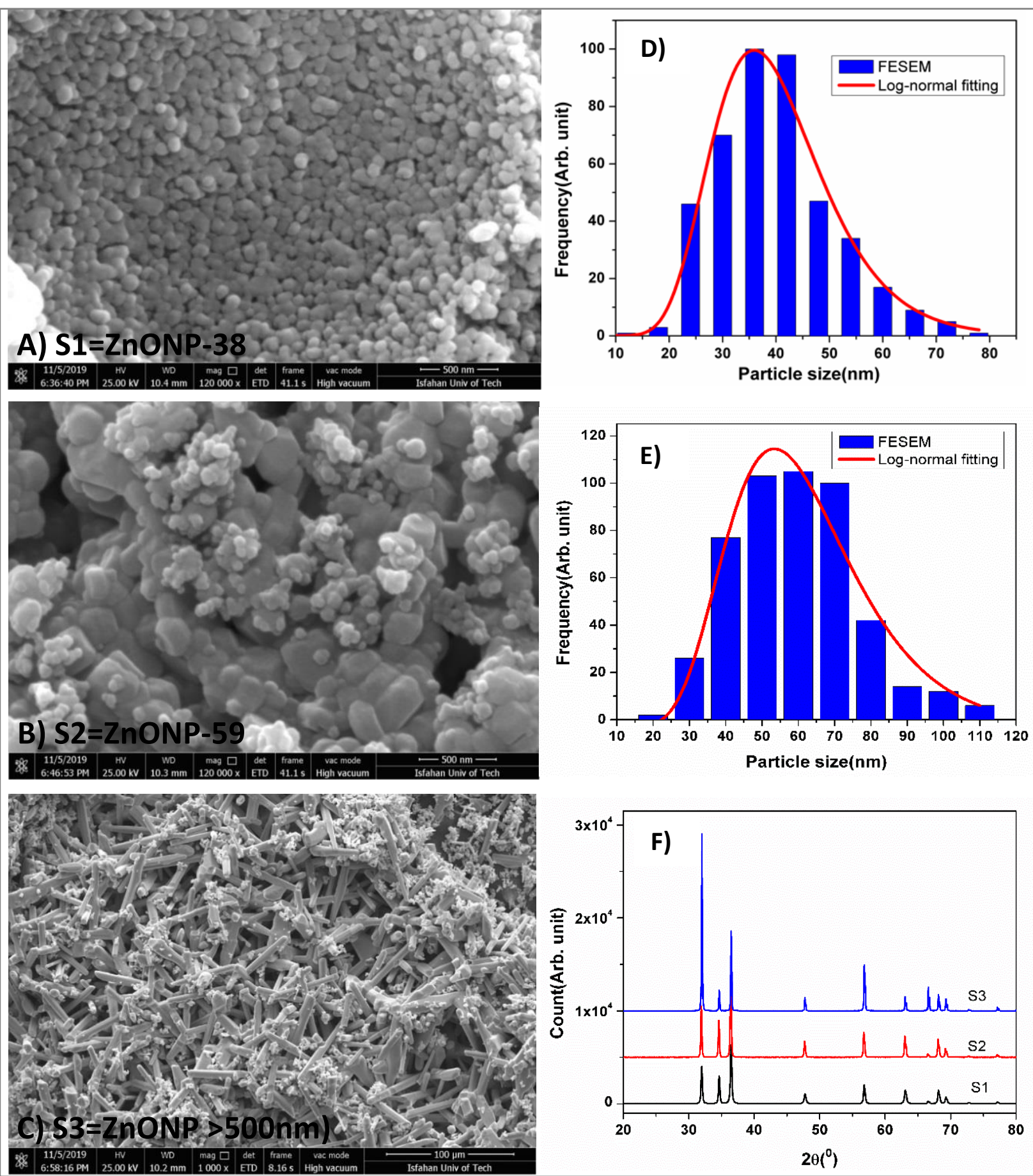

Fig. 1. FE-SEM micrographs of the three morphologically distinct ZnONPs: A) S1 (spherical/ 38nm diameter); B) S2 (floral-like/ 59nm diameter); and C) S3 (rod-like/ >500nm diameter and length $>1 \mu \mathrm{m}$ ). Particle size distribution (PSD) of sample S1 (D) and sample S2 (E). F) XRD patterns of the powder samples of the three morphologically distinct ZnONPs: S1, S2, and S3. 


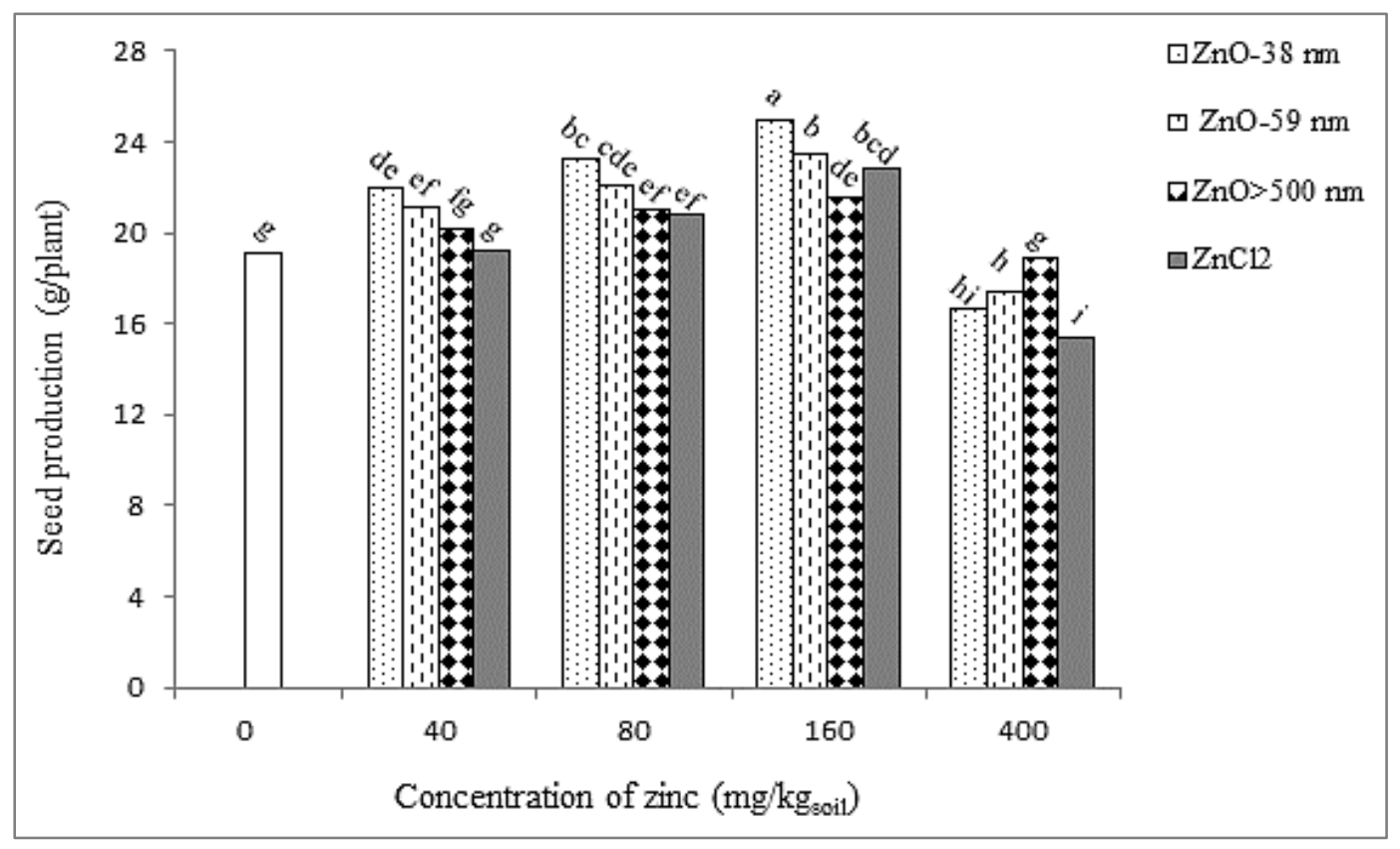

Fig. 2. Seed production in soil grown soybean treated with different types of zinc compounds (spherical ZnONP-38nm, floral-like ZnONP-59nm, rod-like ZnONP>500nm, and $\mathrm{Zn}^{2+}$ ions) as a function of concentrations (0, 40, 80, $160,400 \mathrm{mg} \mathrm{Zn/kg}$ soil). Error bars represent mean \pm SD. Different letters above the bar indicate significant difference at $p<0.05$. 


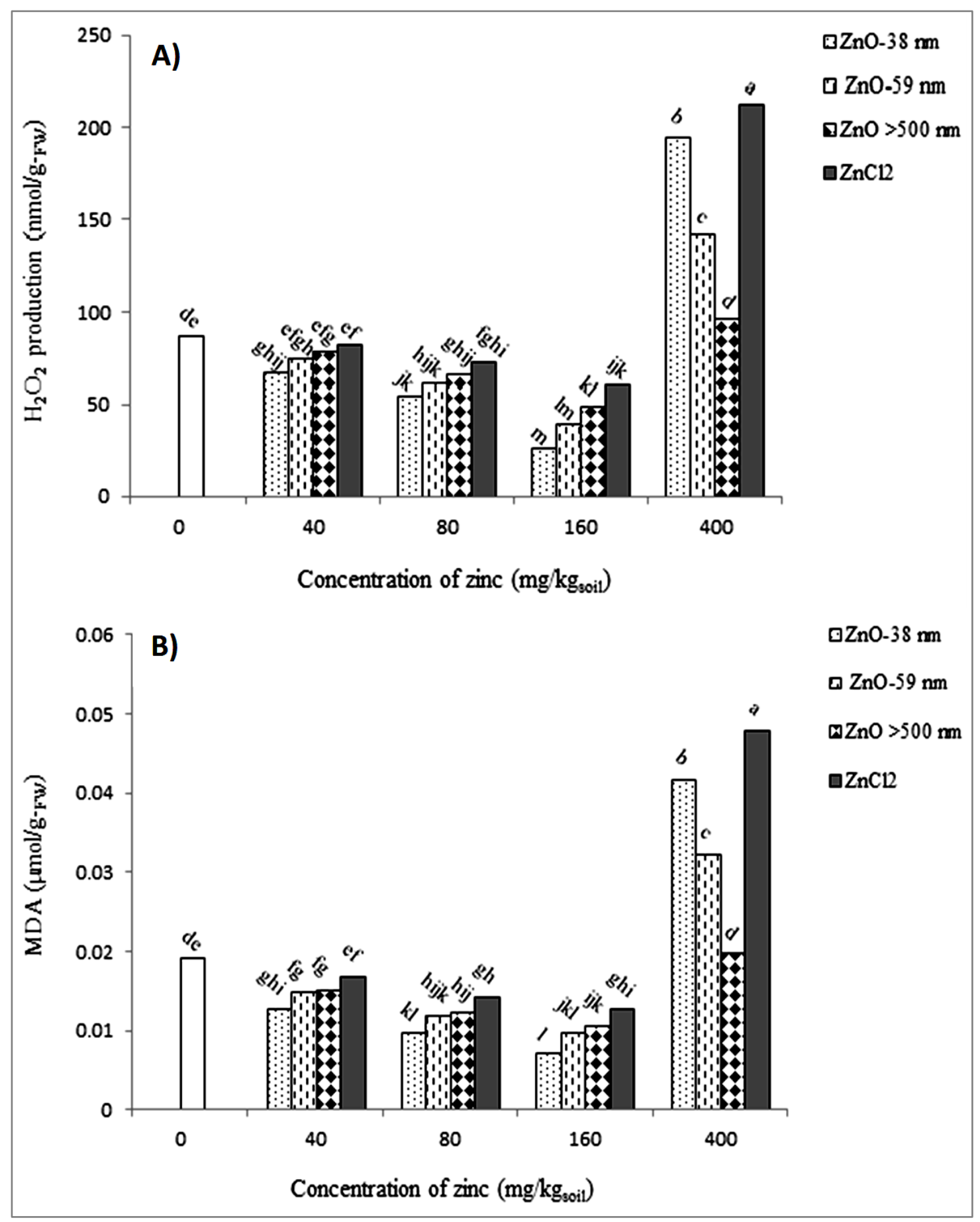

Fig 3. Changes in leaf hydrogen peroxide $\left(\mathrm{H}_{2} \mathrm{O}_{2}\right)$ production $(\mathbf{A})$, and leaf malondialdehyde (MDA) content (B), in soil grown soybean treated with different types of zinc compounds (spherical ZnONP-38nm, floral-like ZnONP-59nm, rod-like $\mathrm{ZnONP}>500 \mathrm{~nm}$, and $\mathrm{Zn}^{2+}$ ions) as a function of concentrations (0, 40, 80, 160, $400 \mathrm{mg} \mathrm{Zn/kg} \mathrm{soil).} \mathrm{Error} \mathrm{bars} \mathrm{represent} \mathrm{mean} \pm$ SD. Different letters above the bar indicate significant difference at $p<0.05$. 


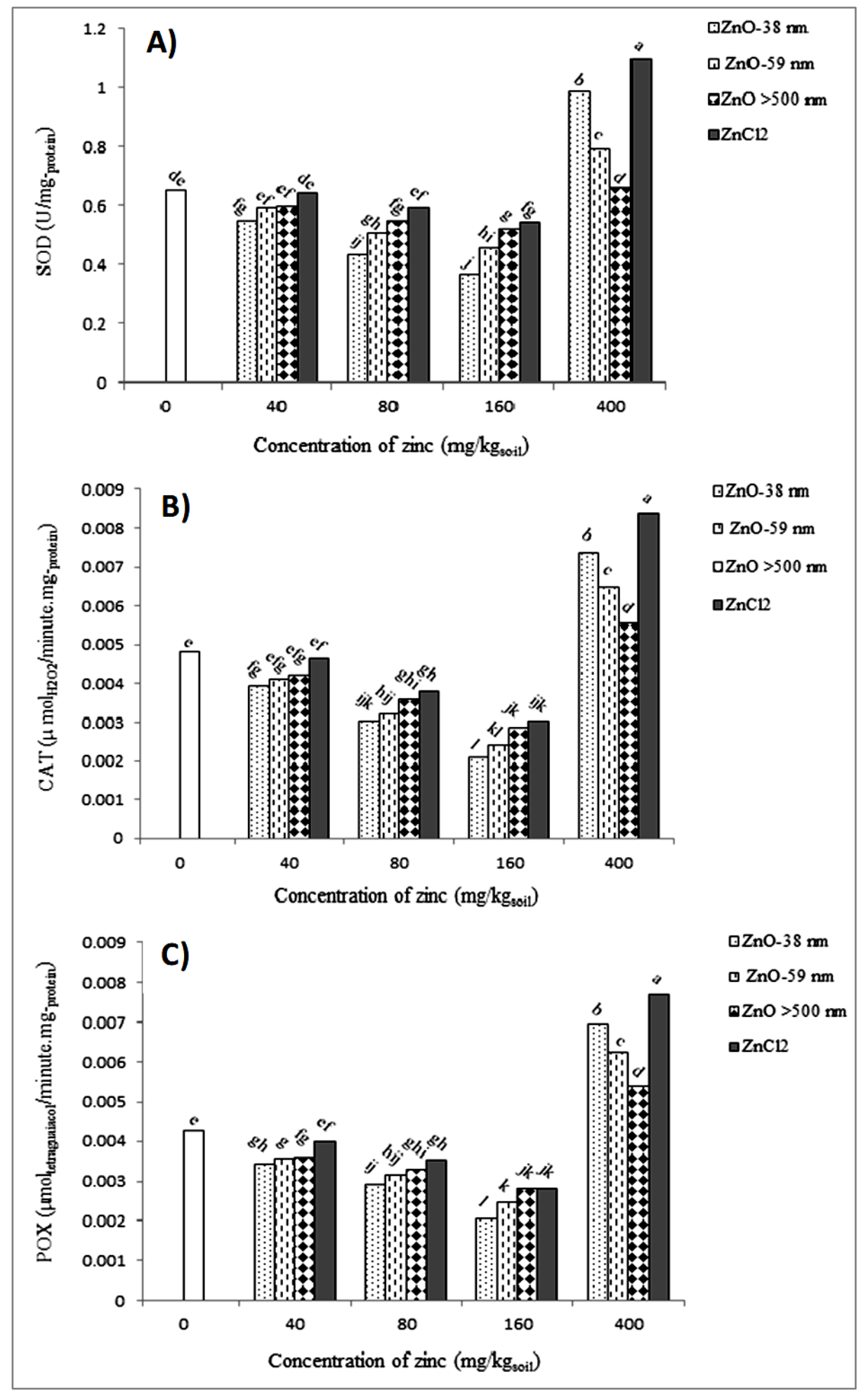

Fig 4. Changes in leaf superoxide dismutase (SOD) (A), catalase (CAT) (B), and guaiacol peroxidase (POX) (C), activities in soil grown soybean treated with different types of zinc compounds (spherical ZnONP-38nm, floral-like ZnONP-59nm, rod-like ZnONP>500nm, and $\mathrm{Zn}^{2+}$ ions) as a function of concentrations (0,40, 80, 160, $400 \mathrm{mg} \mathrm{Zn/kg} \mathrm{soil).} \mathrm{Error} \mathrm{bars} \mathrm{represent}$ mean \pm SD. Different letters above the bar indicate significant difference at $p<0.05$. 


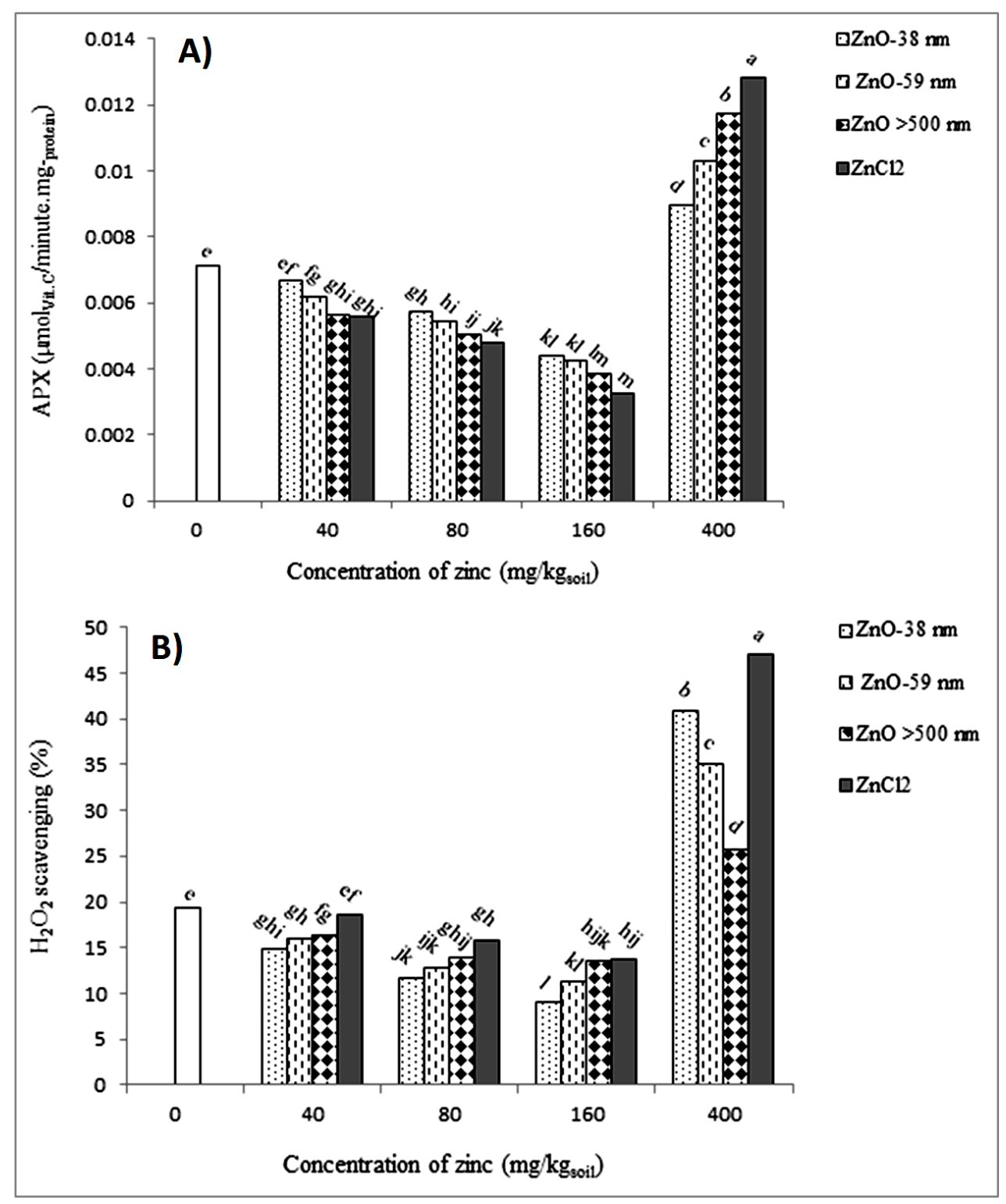

Fig. 5. Changes in leaf ascorbate peroxidase (APX) (A), and $\mathrm{H}_{2} \mathrm{O}_{2}$ scavenging (B) activities in soil grown soybean treated with different types of zinc compounds (spherical ZnONP-38nm, florallike $\mathrm{ZnONP}-59 \mathrm{~nm}$, rod-like $\mathrm{ZnONP}>500 \mathrm{~nm}$, and $\mathrm{Zn}^{2+}$ ions) as a function of concentrations (0, 40, $80,160,400 \mathrm{mg} \mathrm{Zn} / \mathrm{kg}$ soil). Error bars represent mean \pm SD. Different letters above the bar indicate significant difference at $p<0.05$. 
Table 1. Dynamic light scattering (DLS) measurement of hydrodynamic diameter (HDD) and zeta potential values for: (S1) spherical ZnONP-38nm, (S2) floral-like ZnONP-59nm, and (S3) rod-like ZnONP >500nm.

\begin{tabular}{|lcc|}
\hline Sample & Zeta Potential $(\mathbf{m V})$ & HDD $(\mathbf{n m})$ \\
\hline S1 = spherical ZnONP-38nm & -44.8 & 139 \\
\hline S2 = floral-like ZnONP-59nm & -50.4 & 194 \\
\hline $\begin{array}{l}\text { S3 = rod-like ZnONP } \\
\text { >500nm }\end{array}$ & -54.6 & 1059 \\
\hline
\end{tabular}

Table 2. Analysis of variance ( $p$-value) for seed production and biochemical parameters of soybean grown in soil treated with different concentration of zinc compound types.

\begin{tabular}{|lcccc|}
\hline Source of variation & $\begin{array}{c}\text { Seed } \\
\text { production }\end{array}$ & $\begin{array}{c}\mathrm{H}_{2} \mathrm{O}_{2} \\
\text { production }\end{array}$ & $\begin{array}{c}\mathrm{H}_{2} \mathrm{O}_{2} \\
\text { scavenging }\end{array}$ & $\begin{array}{c}\text { Malondialdehyde } \\
(\text { MDA })\end{array}$ \\
\hline Zinc compound type $\left(Z \mathrm{n}_{\text {type }}\right)$ & $<.0001$ & $<.0001$ & $<.0001$ & $<.0001$ \\
\hline Concentration $(\mathrm{C})$ & $<.0001$ & $<.0001$ & $<.0001$ & $<.0001$ \\
\hline$Z \mathrm{n}_{\text {type }} \times \mathrm{C}$ & $<.0001$ & $<.0001$ & $<.0001$ & $<.0001$ \\
\hline
\end{tabular}

Table 3. Analysis of variance ( $p$-value) for antioxidant enzymes activity of soybean grown in soil treated with different concentration of zinc compound types.

\begin{tabular}{|lcccc|}
\hline Source of variation & SOD & CAT & POX & APX \\
\hline Zinc compound type $\left(\mathrm{Zn}_{\text {type }}\right)$ & $<.0001$ & $<.0001$ & $<.0001$ & $\mathrm{~ns}$ \\
\hline Concentration $(\mathrm{C})$ & $<.0001$ & $<.0001$ & $<.0001$ & $<.0001$ \\
\hline$Z \mathrm{n}_{\text {type }} \times \mathrm{C}$ & $<.0001$ & $<.0001$ & $<.0001$ & $<.0001$ \\
\hline
\end{tabular}

ns, non-significant at $p<.05$. SOD, superoxide dismutase; CAT, catalase; POX, guaiacol peroxidase; APX, ascorbate peroxidase. 


\section{Supplementary Information}

\section{Zinc Oxide Nanoparticles (ZnONPs) as Nanofertilizer: Improvement on Seed Yield and Antioxidant Defense System in Soil Grown Soybean (Glycine max cv. Kowsar)}

${ }^{1}$ Yusefi-Tanha, Elham; ${ }^{1 *}$ Fallah, Sina; ${ }^{2}$ Rostamnejadi, Ali; ${ }^{3}$ Pokhrel, Lok Raj

${ }^{1}$ Department of Agronomy, Faculty of Agriculture, Shahrekord University, Shahrekord, Iran

2 Department of Electroceramics and Electrical Engineering, Malek Ashtar University of

Technology, Iran. Email: rostamnejadi@mut-es.ac.ir.

${ }^{3}$ Department of Public Health, The Brody School of Medicine, Department of Health Education and Promotion, College of Health and Human Performance, East Carolina University, Greenville, NC, USA.

*Corresponding authors: LR Pokhrel, Phone: 252-737-5587; Email: pokhrell18@ecu.edu.

S Fallah, Phone: +983832324428; Email: falah1357@yahoo.com. 
Table S1. R-squared values based on the linear regression lines for multiple parameters tested for different sized $\mathrm{ZnONPs}$ and $\mathrm{ZnCl}_{2}$ treatments in soybean. To determine if the concentrationresponse curves were linear (monotonic) or nonlinear (nonmonotonic), we coupled visual inspection of the curves with a simple decision rule: if the co-efficient of determination (R-squared) value for the linear regression line is $65 \%$ or higher the concentration-response curves were deemed linear, suggesting that the plant response changes linearly with the concentration applied. 'L' denotes linear, and 'NL' denotes nonlinear, concentration-response relationships.

\begin{tabular}{|c|c|c|c|c|}
\hline \multirow[b]{2}{*}{ Parameters } & \multicolumn{4}{|c|}{ R-squared } \\
\hline & $\begin{array}{c}\text { ZnONP-38 } \\
\text { nm }\end{array}$ & ZnONP-59 nm & $\begin{array}{c}\text { ZnONP>500 } \\
n m\end{array}$ & $\mathrm{ZnCl}_{2}$ \\
\hline Seed production & $0.22(\mathrm{NL})$ & $0.20(\mathrm{NL})$ & $0.066(\mathrm{NL})$ & $0.32(\mathrm{NL})$ \\
\hline $\mathrm{H}_{2} \mathrm{O}_{2}$ & $0.46(\mathrm{NL})$ & $0.33(\mathrm{NL})$ & $0.044(\mathrm{NL})$ & $0.63(\mathrm{NL})$ \\
\hline MDA & $0.50(\mathrm{NL})$ & $0.42(\mathrm{NL})$ & $0.047(\mathrm{NL})$ & $0.64(\mathrm{NL})$ \\
\hline SOD & $0.36(\mathrm{NL})$ & $0.22(\mathrm{NL})$ & $0.036(\mathrm{NL})$ & $0.61(\mathrm{NL})$ \\
\hline CAT & $0.29(\mathrm{NL})$ & $0.21(\mathrm{NL})$ & $0.10(\mathrm{NL})$ & $0.45(\mathrm{NL})$ \\
\hline POX & $0.37(\mathrm{NL})$ & $0.34(\mathrm{NL})$ & $0.26(\mathrm{NL})$ & $0.51(\mathrm{NL})$ \\
\hline APX & $0.16(\mathrm{NL})$ & $0.33(\mathrm{NL})$ & $0.42(\mathrm{NL})$ & $0.42(\mathrm{NL})$ \\
\hline $\mathrm{H}_{2} \mathrm{O}_{2}$ Scavenging & $0.51(\mathrm{NL})$ & $0.49(\mathrm{NL})$ & $0.37(\mathrm{NL})$ & $0.64(\mathrm{NL})$ \\
\hline
\end{tabular}

